Makale Geliş | Received: 22.12.2020

Makale Kabul | Accepted: 05.01.2021

DOI: 10.18795 /gumusmaviatlas. 834898

Mavi Atlas, 9(1)2021: 250-274

Araştırma Makalesi | Research Article

\begin{abstract}
Nesibe Ayşe SAĞLAM
Arş. Gör Dr.| Res. Assist. Dr

Erzurum Teknik Üniversitesi, Edebiyat Fakültesi, Sosyoloji Bölümü, Erzurum-TÜRKIYE

Erzurum Technical University, Faculty of Literature, Department of Sociology, Erzurum-TURKEY

ORCID: 0000-0001-8969-8270

nesibe.saglam@erzurum.edu.tr
\end{abstract}

\title{
Göçmenlikten Yerleşikliliğe: Gagauz Kadınların Evlilik Deneyimleri ${ }^{1}$
}

Öz

Türkiye'de küreselleşme süreciyle yoğunlaşan uluslararası insan hareketliliğiyle göçmen gruplar ile evlenenlerin sayısı artmışır. Türkiyeli erkeklerin yaygın olarak evlendiği gruplardan biri Moldova vatandaşı olan göçmen Gagauz kadınlardır. SSCB’nin dağılmasıyla Gagauz kadınlar, genellikle ilk olarak iş amacıyla Türkiye'ye gelmiş/gelmektedir. Sonrasında onlardan bazıları Türkiyeli erkeklerle evlenerek Türk toplumuna entegre olmuşlardır. Bu evlilikler, iki toplum arasındaki etnik ilişkilere, sosyal sınırlara ve sosyal mesafenin boyutuna önemli bir ışık tutmaktadır. Bu çalışma, Gagauz kadınların Türkiyeli erkeklerle evlenmeleriyle gündelik yaşamları ve kimlik algılarında ne gibi değişiklikler yaşadıklarını anlamaya ve açıklamaya çalışmaktadır. Ayrıca çocukların yetiştirilmesi ve kimliklenmesi konusuna kadınların ve eşlerinin nasıl bir yaklaşım sergilediklerini incelemektedir. Bu çerçevede, 1996-2018 yılları aralığında Türkiyeli erkeklerle evlenmiş, İstanbul ve İzmir'de yaşayan 11 Gagauz Kadın ile derinlemesine görüşme gerçekleştirilmiştir. Araştırma, 2020 Kasım ayında 6'sı yüz yüze 5’i internet üzerinden çevrimiçi olarak gerçekleştirilen nitel araşırıma yöntemlerinden yarı yapılandırılmış forma dayanan birebir görüşme tekniğiyle yapılmıştır.

Araşıırma sonucunda kadınların gündelik yaşamlarındaki değişimlerin ilk olarak Türkiye’ye göçleriyle başladığı, Türkiyeli erkeklerle evlenmeleriyle süreklilik kazandığı ve onlara zamanla yenilerinin eklendiği görülmüştür. Bunların genellikle dinikültürel ritüel ve törenleri, yeme-içme-giyim pratikleri, Gagauzca-Rusçanın yanı sıra Türkçe konuşmaları vb. ile ilgili değişimler olduğu anlaşılmıştır. İki grup arasındaki temel sosyal sınırın "din" farklılığı olduğuna işaret edilmiştir. Ancak bu sosyal sınırın aile içerisinde gerek eşler arasındaki ilişkilerde gerek çocukların yetiştirilmesi ve kimliklenmesi konusunda sorunlara yol açmadığı bulgulanmıştır. Gagauz kadınların evlilikleriyle süreklilik kazanan Türk toplumuyla uzun süreli etkileşimleri kimliklerini de etkilemiştir. Türk toplumuna aidiyetlerinin boyutuna göre onların bazısı kendini Gagauz, bazısı Gagauz Türkü olarak tanımlarken bazıları kendilerini Türk gibi hissetmektedir.

Anahtar Sözcükler: Göçmen Gagauz Kadınlar, Türkiyeli Erkekler, Gruplar Arası Evlilik, Çoklu Kimliklenme.

\section{From Immigration to Settlement: Marriage Experiences of Gagauz Women}

\section{Abstract}

The number of people married to immigrant groups has increased on the occasion of intensifying international human mobility with the globalization process in Turkey. One of the groups that Turkish men widely married is immigrant Gagauz women who are citizens of Moldova. Gagauz women first came/come to Turkey for business purposes generally with the disintegration of the USSR. Afterwards, some of them are married to Turkish men and integrated into Turkish society. These marriages shed light significantly on ethnic relations, social boundaries, and the extent of social distance between the two communities. In this study, the changes Gagauz women experienced in their daily lives and in their sense of identity by marrying Turkish men are tried to understand and explain. It also examines how women and their husbands approach the issue of raising and identifying children. In this context, in-depth interviews were conducted with 11 Gagauz women who were married to Turkish men in the 1996-2018 year range and lives in İstanbul and İzmir. The research was conducted

\footnotetext{
${ }^{1}$ Erzurum Teknik Üniversitesi Bilimsel Araştırma ve Yayın Etik Kurulu 27.11.2020 tarih ve 9/1 sayılı kararıyla bu araştırmanın etik ilkelere uygun olduğu onaylanmıştır.
} 


\section{SAĞLAM, Nesibe Ayşe (2021). “Göçmenlikten Yerleşikliliğe: Gagauz Kadınların Evlilik Deneyimleri”, Mavi Atlas, 9(1): 250-274}

using the one-to-one interview technique based on semi-structured form, one of the qualitative research methods, 6 of interviews are conducted face-to-face, and 5 of which are conducted online, in November 2020.

As a result of the research, it is observed that the changes in women's daily life first began with the migration to Turkey, gained continuity with marrying Turkish men and new ones have been added to them over time. These changes generally include religious-cultural rituals and ceremonies, eating-drinking-dressing practices, speaking Turkish as well as GagauzRussian, etc. It has been pointed out that the main social boundary between the two groups is the "religion" difference. It has been found that this social boundary does not cause problems in the family regarding relations between spouses or the upbringing and identification of children. The long-term interactions of Gagauz women with Turkish society, which gained continuity with their marriage, also affected their identity. According to the extent of their belonging to Turkish society, some of them define themselves as Gagauz and some as Gagauz Turks, while others feel like Turks.

Keywords: Immigrant Gagauz Women, Turkish Men, Inter Group Marriage, Multiple Identification.

\section{Giriş}

İçinde bulunduğumuz küreselleşme süreci "göçler çağı”’2 olarak tanımlanmaktadır. Günümüzde çeşitli nedenlerle insanlar hızla yer değiştirmekte, göç etmektedir. Göçler, önceden dünya genelinde çoğunluk olarak erkekler tarafından gerçekleştirilirken küreselleşmeyle birlikte kadınların da azımsanmayacak oranda göç ettiği görülmektedir. Uluslararası göçün kadınsılaşmasıyla ilgili de pek çok veri mevcuttur (Kofman et al., 2000, S. Castles \& M. J. Miller, 2008; Ünlütürk-Ulutaş ve Kalfa, 2009). Türkiye'de de göçün kadınsılaşması eğilimi yaşanmaktadır (Dedeoğlu ve Ekiz Gökmen, 2011: 137). Özellikle SSCB'nin dağılmasıyla 1990'lı yıllar sonrasında eski Sovyet halklarından gelen yoğun bir kadın göçüyle karşılaşmıştır. Bunların içerisinde Rus, Ukraynalı, Bulgar, Moldovalı, Romen vb. farklı etnik gruplarla birlikte azımsanmayacak oranda Türk asıllı Özbek, Kazak, Türkmen gibi büyük gruplar ve bunların yanı sıra Azeri Türkleri, Ahıska Türkleri, Misket Türkleri ve Gagauzlar gibi küçük Türk grupları da bulunmaktadır (Aktaran Lordoğlu, 2007: 90,97). Gagauzlardan genellikle -kadınlar- 1990’lı yıllardan itibaren iş/çalışmak amacıyla Türkiye'ye gelmiş/gelmektedirler. ${ }^{3}$ Bu kadınlar, ilk çoğunluk olarak "ev hizmetleri”" sektöründe çalışış/çalışmaktadır. ${ }^{4}$ Onlar genellikle ev temizliği, çocuk, hasta ve yaşlı bakıcılığı gibi işler yapmışlar/yapmaktadırlar (Chirciu, 2014: 5; Kaşka, 2007: 233; 2016: 80; Keough, 2003; Ünal, 2012: 389; Demirdirek, 2007: 16-17). Günümüzde ise yine "ev hizmetleri" sektöründe hasta, çocuk, yaşlı bakıcıllğı, ev temizliği, yemek işleri vb. yanı sıra tekstil sektörü içerisinde mağazalarda satış temsilciliği, taşımacılık sektörü ve tercümanlık (Rusça) gibi alanlarda da çalışmaya devam etmektedirler. İş alanlarının çeşitlenmesine rağmen yine de “Türkiye'de özellikle büyük kentlerde ev içi hizmetlerde çalışan emek ihtiyacı gündeme geldiğinde akla hemen Moldovalılar gelmektedir. Aslında bu tür hizmetler başlangıç yıllarından farklı olarak sadece Moldovalılar tarafından

\footnotetext{
2 S. Castles \& M. J. Miller, 2008

3 SSCB dağıldıktan sonra Gagauz Yeri Özerk Bölge'si uzun bir sosyo-ekonomik kriz sürecine girmiş, kolhozlar dağılmış, var olan firmalar kapatılmıştır. Ayrıca -tarım ve hayvancilık dışında- farklı iş alanlarının olmaması ve ücretlerin düşüklüğü nedeniyle insanlar ciddi maddi sorunlarla karşı karşıya kalmıştır. Enflasyonun ve işsizlik oranın artmasıyla anne ve babalar çocuklarını aile büyüklerine bırakarak iş bulmak ve ailenin geçimini sağlamak için başka bir ülkeye gitmek zorunda kalmışır (Chirciu, 2014: 5). Kadınlar çoğunlukla Türkiye'ye, erkekler ise Rusya'ya gitmeyi tercih etmiş/etmektedir (Karanfil, 2015: 55).

4 “'Türkiye 1990'ların ikinci yarısından itibaren, dağılan Sovyetler Birliğ̣’’nin çeşitli ülkelerinden özellikle ev işleri alanında çalışmak için gelen kadınlarla tanıştı. Öncelikle Türk kökenli Bulgaristan vatandaşları ve Gagavuz asıllı Moldovalı kadınlarla başlayan göç, 2001 ekonomik kriziyle bir durgunluğa uğradıysa da 2003 yılından beri artan bir hızla devam etmektedir" (Akalın, 2000: 118). Bu kadınların çalışmak için Türkiye'yi tercihleri ise daha çok kendi ülkelerine yakınlık ve daha önce Türkiye'ye gelenlerin kendilerine verdikleri referansla ve kendi ülkeleriyle Türkiye arasındaki kültürel ilişkiler ile ilgilidir (Lordoğlu, 2007: 112). Türkiye’ye eğitim amacıyla da Gagauz kadınlar göç etmektedir ancak bu sınırlı sayıdadır. Bu çalışmanın katılımcıları Türkiye'ye iş/çalışmak için gelmiş sonrasında Türkiyelilerle evlenenlerden oluşmaktadır.
} 


\section{SAĞLAM, Nesibe Ayşe (2021). “Göçmenlikten Yerleşikliliğe: Gagauz Kadınların Evlilik Deneyimleri”, Mavi Atlas, 9(1): 250-274}

yerine getirilmemektedir; Türkmen, Özbek, Azeri, Bulgar, Ermeni kadınlar da bu işlerde istihdam edilmektedir. Ancak Moldovalılar-Gagauzlar- neredeyse bu işlerle özdeşleşmiş durumdadırlar" (Kaşka, 2007: 233). Onların dillerinin Türkçeye yakın olması, dürüst ve iyi insanlar olarak tanınmaları, Türk köylüleriyle karşılaştııldığında daha temiz, okur-yazar, medeni ve daha Avrupalı olmaları, hızlı öğrenmeleri ve ev içi hizmetlere daha kolay uyum sağlamaları tercih edilmelerini ve söz konusu sektörle Özdeşleştirilmelerini sağlamıştır (Keough, 2003: 74; Kaşka, 2016: 80). İstanbul, Ankara, Antalya, İzmir gibi büyük kentlerde çalışan pek çok Gagauz kadın bulunmaktadır. Onlar Türkiye'de resmi kayıtlara Moldova vatandaşı olarak geçtikleri için tam olarak sayıları bilinmemektedir. Ancak Türkiye'deki Gagauzların 10.000-40.000 aralığında veya $25.000^{5}$ olduğuna dair iddialar söz konusudur (Aksoy, 2016: 251). Bu nüfusun önemli bir kısmını buraya çalışmak amacıyla gelen kadınların oluşturduğu düşünülmektedir. ${ }^{6}$ Bu kadınlardan kısa süreli olarak çalışıp ülkelerine dönenler olduğu gibi uzun süreli yaklaşık 20-25 yıldır Türkiye'de çalışan kadınlar da bulunmaktadır. ${ }^{7}$ Bunların yanı sıra az da olsa ailesini Türkiye'ye getirenler veya kendine bir yaşam kurup burada kalıcılaşanlarla birlikte Türkiyeli ${ }^{8}$ erkeklerle evlenerek buraya yerleșen Gagauz kadınların sayıları da azımsanmayacak orandadır. Bu oranı, resmi rakamlarla9 belirtemesek de tahmini olarak açıklayabiliriz. Örneğin, Türkiye'deki Gagauz göçmen profili şöyle tanımlanmaktadır; Türkiye'ye çalışmak için gelen Gagauzlar, Türkiyelilerle evlenen Gagauzlar, eğitim amaciyla gelen Gagauz öğrenciler ve eğitimleri sonrasında Türkiye'de çalışan/yerleşen farklı (doktor, öğretmen, avukat vb.) meslek sahibi Gagauzlar. ${ }^{10}$ Ayrıca hem Türkiye'deki Gagauz diasporası hem Gagauzya'da yaşayan Gagauzlarla gerçekleştirilen sohbetlerde

\footnotetext{
5 (Canbazoğlu, 2019), Gagauz Dostluk Kültür ve Dayanışma Derneği Başkanı Nejdet Ertuğrul ve Olga Radova Türkiye'de yaşayan Gagauzları anlatmaktadır: https://www.facebook.com/watch/live/?v=222818945222961\&ref=watch_permalink, Gagauzlar Derneği Sekreteri Sergheı Manastırlı Grt'de “Turkiye'deki Gagauzları ve Gagauzlar Derneğini Anlattı”: https://www.facebook.com/gagauzdayanisma/videos/597229030776184

${ }^{6}$ Gagauzlar Türkiye'ye kitlesel olarak kadınlar çalışmak ve gençler ise eğitim amacıyla gelmektedir. Ancak eğitim amacıyla gelenler belli bir kontenjana tabiidir. Ayrıca Gagauz gençler, günümüzde eğitim almak amacıyla sadece Türkiye'yi tercih etmemekte Rusya, Almanya ve diğer AB ülkeleri gibi yerlere de gitmektedirler. Dolayısıyla Türkiye’ye eğitim amaciyla gelen öğrencilerin çalışmak için gelen kadınlara oranla daha düşük sayıda olduğu tahmin edilmektedir.

${ }^{7 " M o l d o v a l ı ~ k a d ı n l a r(G a g a u z l a r) ~ T u ̈ r k i y e ’ y e ~ b i r ~ a y l ı k ~ t u r i s t ~ v i z e s i ~ i l e ~ y a s a l ~ o l a r a k ~ g i r i s ̧ ~ y a p m a k t a d ı r l a r . ~ A n c a k ~ v i z e ~ s u ̈ r e s i n i n ~}$ bitiminden sonra Türkiye'de kalmaya devam etmekte ve düzensiz göçmen durumuna düşmektedirler” (Kaşka, 2016: 7980). “ 'Türk Kökenli Yabancılar' kategorisine giren Gagauz kadınların üç aya kadar yasal, altı aydan kısa olmak üzere yasadışı olmak üzere toplam dokuz ay Türkiye'de kalışları, çalışmaları ve ardından küçük bir miktar ceza ödeyerek ülkelerine geri dönmeleri söz konusudur. Türkiye'de kalışları yasadışı duruma gelenler, tahdite konu olmakta; bir başka deyişle, Türkiye'den çıkış yaptıklarında, Türkiye'de yasadışı geçirdikleri zaman kadar, ülkelerinde kalma zorunlulukları olmaktadır. $\mathrm{Bu}$, yasadışı duruma düşen Gagauz kadının ailesi için yeniden Türkiye’ye gelişinin ertelenmesi anlamına gelmektedir. Cezalı duruma düşen Gagauz kadının yerine aileden bir başka kadın görevlendirilmekte ve Türkiye'ye giriş yaparak önceki akrabasının çalışıı̆̆ işyerinde onun bıraktı̆̆ yerden devam etmektedir. Bu sadece Türkiye'ye göçen kadının geliştirdiğgi bir çözüm yolu değil, kadının Moldova'daki hanesi tarafından da geliştirilen "Döngüsel Göç (Rotational Migration)" olarak tanımlanabilecek yaşamsal bir stratejidir" (Ünal, 2012: 395). "Tarihsel, kültürel, etnik ve etik gerekçelerden dolayı, Gagauz göçmenler diğer göçmenlere nazaran çok fazla yasal sorun yaşamamakta ve yasa dışıllklarını avantaja çevirebilmede de zorlanmamaktadırlar" (Ünal, 2012: 399). Dolayısıyla bu durum Gagauz kadınların Türkiye'de bu iş alanında süreklilik kazanmasına neden olmaktadır. Ayrıca süreç içerisinde vatandaşlık veya oturum haklarından yararlanarak uzun süre Türkiye'de kalma hakkı elde edenler de söz konusudur.

8 Türkiyeli terimi, Türkiye'de yaşayan tüm etnik ve dini grupları kapsaması yönüyle tercih edilmiştir.

${ }^{9}$ Gagauzlar, resmi kayıtlarda-Gagauz değil- Moldova vatandaşı olarak tanımlanmaktadır.

${ }^{10}$ Gagauzlar Derneği Sekreteri Serghe1 Manastrllı Grt'de “Turkiye'deki Gagauzları ve Gagauzlar Derneğini Anlattı":https://www.facebook.com/gagauzdayanisma/videos/597229030776184,

Gagauz Dostluk Kültür ve Dayanışma Derneği Başkanı Nejdet Ertuğrul ve Olga Radova Türkiye'de yaşayan Gagauzları anlatmaktadir: https://www.facebook.com/watch/live/?v=222818945222961\&ref=watch_permalink
} 


\section{SAĞLAM, Nesibe Ayşe (2021). “Göçmenlikten Yerleşikliliğe: Gagauz Kadınların Evlilik Deneyimleri”, Mavi Atlas, 9(1): 250-274}

Türkiyelilerle evlenen Gagauz kadınların yoğunluğundan sıklıkla bahsedilmektedir. Örneğin, Türkiye'de Gagauzlarla ilgili düzenlenen kültürel organizasyonlarda bu kadınlarla karşılaşılmakta ve onlar gibi burada evlenenlerin çokluğuna değinilmektedir. Bu çalışmanın katılımcıları da görüşmeler esnasında çok var benim gibi Türkiyelilerle evlenen diyerek arkadaşlarından örnekler vermişlerdir. Gagauzya'da da görüşülen bazı kişiler de -benim kızım orda Türk'le evli, benim kardeşimin kızı evli, komşumuz evli size şeklinde- pek çok tanıdığından bahsetmişlerdir (Sağlam, 2019: 118-122). Netice itibariyle Türkiyeli erkeklerle evlenen Gagauz kadınların belli bir yoğunluğa sahip olduğu anlaşılmaktadır. Dolayısıyla iki grup arasındaki evlilikler araştırılmaya değerdir. ${ }^{11}$

Gagauzlar; Türk kökenli, Türk dillerinden Gagauzca anadiline sahip, Gagauzca-Rusça konuşan Ortodoks Hristiyan dinine bağlı bir topluluktur. Türk kökenli ve Türk dilli olmalarıla Türk toplumuna yakın olsalar da dinleri ve geçmişte SSCB'de yaşamış olmaları nedeniyle inanç, yaşama dair alg1, kültür, dil, gündelik yaşam pratikleriyle vb. onlardan önemli ölçüde ayrılmaktadırlar. Bu nedenle Gagauzlar ve Türkiyeliler arasında gerçekleşen evlilikleri gruplar arası hatta hem etniler arası hem dinler arası evlilik olarak değerlendirmekteyiz. ${ }^{12}$ Gruplar arası evlilikler; etnik, 1rksal, dini gruplar arası ilişkileri sosyolojik olarak anlamak ve açıklamak açısından ciddi önem taşımaktadır. Burada da göçmen Gagauz kadınlar ve Türkiyeli erkeklerin evliliklerinin incelenmesiyle iki grup arasındaki etnik ilişkilere, sosyal sınırlara, sosyal mesafenin boyutuna -sınırlı da olsa- bir ışık tutulması amaçlanmaktadır. Çalışmada bu evliliği gerçekleştiren Gagauz kadınların gündelik yaşamları ve kimliklerinin bu evlilikten nasıl etkilendiği, gündelik yaşam pratikleri ve kimlik algılarında ne gibi değişiklikler yaşadıkları anlaşılmaya ve açıklanmaya çalışılmıştır. Ayrıca çocukların yetiştirilmesi ve kimliklenmesi konusuna kadınların eşleriyle birlikte nasıl bir yaklaşım sergiledikleri irdelenmiştir.

\section{Teorik Arka Plan}

\section{Uluslararası Göçler ve Gruplar Arası Evlilik}

Uluslararası insan hareketliliği ve göçler, pek çok farklı etnik, ırksal, dini grupların karşılaşmalarını, etkileşimlerini ve ilişkilerini önemli ölçüde etkilemiş ve dönüştürmüştür. Bu durum gruplar arası evliliklerin artması ve yaygınlaşmasına da ortam hazırlamıştır (Dedeoğlu ve Ekiz Gökmen, 2011; Lucassen \& Laarman, 2009; Törngren et al., 2016). ABD ve Batı Avrupa başta olmak üzere pek çok ülkede farklı etnik, ırksal, dini aidiyete sahip göçmenler ve yerliler veya göçmen gruplar arasında evlilikler yaygınlaşmıştır. Özellikle göçmenler ile yerliler/ev sahibi toplum arasında yaşanan evlilikler, göçmenlerin ev sahibi topluma entegrasyonunda önemli bir gösterge olarak değerlendirilmiştir (Aktaran Dribe \& Lundh, 2008, Garcia, 2008, Schnapper, 2005: 222; Törngren et al., 2016). Gruplar arası evlilikler, insanlığın her döneminde olmakla birlikte özellikle uluslararası göçler, sanayileşme, kentleşme, eğitim seviyesinin yükselmesi, sekülerleşme, bireyselleşme vb. toplumsal değişimlerle birlikte artış göstermiştir (Kalmijn, 1991; Balkanlıŏlu, 2012; Gündüz Hoşgör \& Smith: 2002). Bugünün aileleri daha hareketli ve kentseldir (Gordon,1967: 41) Bu durum toplumların yerleşim alanları (ev, komşu), iş yerleri, okullar vb. yerlerde farklı gruplarla karşılaşma, etkileşime geçme ve ilişki kurma

\footnotetext{
${ }^{11}$ Bu evliliklerin Türk toplumuna oranla Gagauz toplumunu daha fazla etkilediği düşünülmektedir. Çünkü Gagauz toplumu nüfusuna oranla Türkiyeli erkeklerle evlenen Gagauz kadınlar belli bir çoğunluk oluşturmaktadır. Bu durum Gagauz toplumunun Türkiye toplumuyla toplumsal etkileşimi ve ilişkileri noktasında önemli bir göstergedir.

12 Gruplar arası evlilik, genellikle evlilik öncesi veya sonrasında etnik, 1rksal veya dini bagajı birbirinden farklı olan kişilerin yaptıkları evlilikleri tanımlar. Etniler arası evlilik ise, aynı din veya renge sahip kişiler için kullanılabilir ancak ulusal ve kültürel aidiyet olarak farklı olanlarla gerçekleştirilen evliliklerdir (Gordon, 1967: 1). Dinler arası evlilik ise farklı inanç gruplarına mensup kişilerin gerçekleştirdikleri evlilik türü olarak tanımlanmaktadır.
} 


\section{SAĞLAM, Nesibe Ayşe (2021). “Göçmenlikten Yerleşikliliğe: Gagauz Kadınların Evlilik Deneyimleri”, Mavi Atlas, 9(1): 250-274}

ihtimal ve olanaklarını artırmıştır (Kalmijn, 1998: 403; 1991: 790). Bunlar ilk başta sadece toplumsal mekânlarda farklı gruplar arasında karşılaşmaları eskiye göre sıklaştıran ortamların oluşması gibi gözükse de aynı zamanda toplumlarda zihin ve algı değişimini de beraberinde getirmiştir. İnsanlar, uzun yıllardır içinde yaşadıkları geleneksel-dini değerler ve toplumsal normların geçerli olduğu toplumsal ortamdan farklı mekânlara, kentlere, metropollere gittiklerinde (göç ettiklerinde) bu yeni ortamda özgürleşmekte, sekülerleşmekte ve bireyselleşmektedir. Böylece onun eylemleri daha az önyarg1lı ve nesnel standartlara göre belirlenmektedir (Park, 1928: 887-888). Dolayısıyla bu durum insanların birbirlerine yaklaşımlarını ve etkileşimlerini de etkilemektedir. Söz konusu toplumsal değişimlerin etkisiyle de "günümüzde başka bir din, renk, sınıf ya da etnik gruptan biriyle evlenme bir nesil önceye göre daha olağan bir hale olagelmiştir. Bugünün insanlarının iç grup dayanışması daha az belirgindir" (Gordon,1967: 41). Çünkü günümüzde etnik, 1rksal, dini sınırlar artık eskisi kadar güçlü değil, bunlar bulanıklaşmış ve zayıflamıştır (Kalmijn,1991: 787-788; Qian \& Lichter, 2011: 1082; Qian; 1997). Hatta bu toplumsal sınırların yerini yeni sınırlar (eğitim, sosyo-ekonomik statü gibi) almıştır (Kalmijn, 1991: 797; Qian, 1997). "Örneğin şu anda kişilerin eş seçimi tercihlerini etkileyen bir faktör olarak din yerine bireyin eğitimli olup olmadığ1 değerlendirmesi yapılması homogaminin iki türü arasındaki ilişkinin değiştiğini göstermektedir” (Kalmijn, 1991: 796). Şimdilerde kendi inançları dışından evlenen insanların sayısı artmakta ve kendi eğitim grubu içerisinden evlenme daha olasılıklı bir durumdadır (Kalmijn, 1991: 797). Kalmijn, 1920 'lerden 80'lere evlilik tercihlerinde yeni sosyal sınırların ortaya çıtı̆̆ını, 1920'lerden 80’lere Protestan ve Katolikler arasında yükselen evlilik oranlarıyla örneklendirerek açıllamıştır. Bunun öncelikle söz konusu gruplar arasında sosyo-ekonomik statünün yakınlaşmasına bağlandığını ifade eder. Ancak ona göre bunun nedeni sekülerleşmedir. Sekülerleşmeyle birlikte Protestanlar ve Katolikler arasındaki evlilik, doğurganlık, çocuk yetiştirme, cinsellik gibi konulara bakış açısının ve yaşam tarzının benzeşmesiyle dini değerlerin gündelik yaşam üzerindeki etkisinin azalmasıyla gruplar arasında yakınlaşma ve evlilikler artmıştır (Kalmijn, 1991: 797-798). "Esasında gündelik yaşam tarzı ve pratiklerinin benzeşmesi gruplar arası evlilikleri kolaylaştıran en önemli faktör gibi görünmektedir. Burada etnik, 1rksal, dini sınırların eskiye oranla tamamen ortadan kalktığı kastedilmemektedir; ancak söz konusu unsurların insanlar üzerinde belirleyiciliği daha zayıftır” (Kalmijn, 1998: 417). Türkiye'de Alevi-Sünni evlilikleri üzerine Balkanlığlu (2012: 169) ve Çatak (2015: 199-200)'ın çalışmaları da gruplar arasındaki sınırların bireylerin evlilik kararları üzerindeki etkilerinin azaldığı yönündedir.

Gruplar arası evliliklerin sonuçları da gerek bireysel gerek toplumsal açıdan ciddi önem taşımaktadır. Bununla ilgili başta ABD ve Avrupa olmak üzere pek çok ülkede araştırmalar yapılmış ve hâlihazırda yapılmaktadır. Bu çalışmalarda gruplar arası evliliklerin sonuçları çoğunlukla şu kavramlar ekseninde tartışılmaktadır; sosyo-ekonomik statü değişikliği, sosyal mesafelerin azalması, asimilasyon, entegrasyon, etnik çeşitlenme, dual, çoklu kimliklenme, melezleşme vb (Törngren et al., 2016: 509; Özateşler Ülkücan vd.,: 2019). Bu evliliklerle ilgili "pek çok sosyolog, öncelikle şu ortak yaklaşımı benimser; gruplar arası evlilik, çeşitli toplulukları bütünleştirmenin ${ }^{13}$ ve önyarg1lar ile "1rkçıllı̆ı" saf diş1 bırakmanın en etkili yoludur" (Schnapper, 2005: 222; Özateşler Ülkücan vd.,: 2019: 19, 21). "Gruplar arası evlilik gerçekleştiren bireyler, diğer gruplara karşı olan olumsuz düşüncelerini kaybedebilirler. Evlilik genellikle iki eşin sosyal ağlarını birbirine bağladığından bu sadece yakın eşleri değil diğer grup üyeleri için de geçerlidir” (Kalmijn, 1998: 396). Ayrıca eşler arasında birbirlerine uyum sağlama çabasıyla

\footnotetext{
${ }^{13}$ Toplumlararası entegrasyonu sağlama düşüncesi yüzyılın başlarında yapılan çalışmalarda daha çok asimilasyon kavramı ekseninde tartışılmıştır. Özellikle yerli ve göçmenler arasında gerçekleşen evliliklerde göçmenlerin yerlilere her yönüyle uyum sağlaması asimile olması önemli görülmüştür. Günümüzde ise göçmenlerin hem kendi etnik kimliklerini koruyarak hem ev sahibi topluma uyum sağlayarak bütünleşmeyi içeren ‘entegrasyon' kavramı kullanılmaktadır.
} 


\section{SAĞLAM, Nesibe Ayşe (2021). “Göçmenlikten Yerleşikliliğe: Gagauz Kadınların Evlilik Deneyimleri”, Mavi Atlas, 9(1): 250-274}

özellikle göçmen olan tarafın ev sahibi toplumdan olan eşinin dil, kültür, gelenek, din vb. aidiyetlerini benimseme ve içselleştirme durumu olabilir. Böylece evliliği gerçekleştiren bireylerde eş asimilasyonu veya çoklu kimliklenme yaşanabilir (Qian \& Lichter, 2001: 295, 309; García, 2010). Zaten sosyal etkileşim, karşıllklı kimliklenme sonucunu doğurur (Rockquemore, 1998: 210).

Gelecek nesiller açısından ise etnik çeşitlenme yani kendini karma ırklı ve kimlikli tanımlamalar olabilir (Aspinall \& Song, 2013). Kültürel farklılıkların belirginliği azalır. Çünkü gruplar arası evlilik çocuklarının kendilerini tek bir grup kimliğiyle özdeşleştirmeleri daha düşüktür (Kalmijn, 1998: 396). Bu çocuklar, iki grup arasındaki aynılık ve farklılıkların farkında olup bazı değerlere ait olup olmamayı ve kimliklerini bu çerçevede inşa edip etmemeyi de öğrenirler. Ve netice itibariyle kültürel melezleşme yaşarlar (Anderson, 1999: 24-25).

\section{Araştırmanın Evreni ve Yöntemi}

Gagauzlar, günümüzde çoğunluğu Moldova’ya bağlı Gagauz Yeri Özerk Bölgesi olmak üzere Ukrayna, Bulgaristan, Yunanistan, Romanya, Kazakistan, Kırgızistan, Özbekistan, Brezilya gibi farklı ülkelerde yaşamaktadır. Ayrıca SSCB dağıldıktan sonra Gagauzların çoğu iş, eğitim ve daha iyi yaşam olanaklarına erişmek amacıyla Rusya ve Türkiye başta olmak üzere Almanya, Ingiltere, Italya, Amerika vb. ulus-aşırı ülkelere göç etmektedir. Özellikle Türkiye ve Rusya'da önemli bir Gagauz diasporası bulunmaktadır. ${ }^{14}$ Pek çok farklı ülkeye dağılan Gagauzların her ülkedeki göçmenlikleri, yerli ve göçmen gruplarla etkileşimleri, entegrasyonları veya asimilasyonları ayrı bir sosyolojik inceleme konusudur. Bu çalışmada Türkiye'ye emek göçüyle gelen sonrasında Türkiyelilerle evlenenlere odaklanılmaktadır. Araştırma, nitel araştırma yöntemi ile yapılmıştır. ${ }^{15}$ Veriler, ilgili kurumdan gerekli etik kurul izni ve görüşme öncesinde katılımcıların onaylarının alınmasıyla etik kurallar çerçevesinde elde edilmiştir. Postsovyet süreçte (1990-...) Türkiye'ye emek göçüyle gelen sonrasında 1996-2018 y1lları aralığında Türkiyeli erkeklerle evlenen şuanda İstanbul ve İzmir'de yaşayan 11 Gagauz Kadın ile derinlemesine görüşme ${ }^{16}$ gerçekleştirilmiştir. 2020 Kasım ayında 6’sı yüz yüze 5’i çevrimiçi olarak gerçekleştirilen nitel araştırma yöntemlerinden yarı yapılandırılmış forma dayanan birebir görüşme tekniğiyle yapılmıştır.

Katılımcılardan iki kişiyle ilk olarak İstanbul'da düzenlenen Gagauzların düzenlediği kültürel organizasyonlarda tanışılmıştır. Sonrasında bu kişilerin tanıdıkları ile de iletişime geçilerek amaçlı ve kartopu örneklem teknikleriyle katılımcılar belirlenmiştir. Katılımcılarla uygun zaman ve yer belirlenerek görüşmeler yapılmıştır. Yüz yüze görüşmeler, çoğunlukla kadınların kendi evleri veya kendi talepleri doğrultusunda seçtikleri kamusal alanlarda gerçekleştirilmiştir. Çevrimiçi görüşmeler ise sosyal medya araçlarından "facebook" üzerinden görüntülü kamera ile yapılmıştır. Görüşmeler kişilerin izinleri dâhilinde ses kayıt cihazlarına kaydedilmiştir. Bu kayıtlar deşifre edilerek betimsel analiz tekniğiyle analiz edilmiştir. Betimsel analiz, "araştırmaya konu olan kültürün tanımlanması ve bu süreçte de bu kültürü oluşturan bireylerin ya da grupların algılarının, deneyimlerinin ve tutumlarının kendi bakış açılarından aktarılmasını gerektirir. Dolayısıyla ortaya çıkan bulgular, söz konusu çalışılan grubu yansıtması açısından onun diliyle sunulur ve doğrudan alıntılara sık yer verilir" (Yıldırım ve Şimşek, 2016: 69). Aynı zamanda bu veriler, dikkatli ve ayrıntılı bir şekilde oluşturulan belli temalar ve

\footnotetext{
${ }^{14}$ Kadınlar genellikle Türkiye’ye “ev hizmetleri”nde çalışmaya gelirken erkekler ise Rusya’ya “inşaat sektörü”nde çalışmaya gitmektedir.

${ }^{15}$ Nitel araştırma, “sosyal fenomenleri, insan davranışlarını ve bu davranışların sebeplerinin neler olduğunu detaylı ve derin bir şekilde anlamayı amaçlayan bir araştırma yöntemidir” (Güler vd., 2013: 39).

16 Derinlemesine görüşme, bireylere açık uçlu sorular sorulabilmesi, ilişkili ilave sorularla araştırma konusunun detaylandırılabilmesi, cevapların kaydedilebilmesini mümkün kılması yönüyle tercih edilmiştir (Kümbetoğlu, 2017: 71).
} 
SAĞLAM, Nesibe Ayşe (2021). “Göçmenlikten Yerleşikliliğe: Gagauz Kadınların Evlilik Deneyimleri”, Mavi Atlas, 9(1): 250-274

kodlamalar aracılığıyla anlamlandırılmaya çalışılmıştır (Creswell, 2017: 613). Ardından ilgili literatür çerçevesinde analizin yorumlanmasıyla bulgular değerlendirilmiştir.

\section{Araştırmanın Etik İzinleri}

Araştırma kapsamında "Yükseköğretim Kurumları Bilimsel Araştırma ve Yayın Etiği Yönergesi" kapsamında uyulması belirtilen tüm kurallara uyulmuştur. Araştırmanın etik onayını Erzurum Teknik Üniversitesi Bilimsel Araştırma ve Yayın Etik Kurulu vermiştir.

Etik Kurul Onay Tarihi: 27.11.2020

Etik Kurul Onay Sayıs1: 9/1

\section{Bulgular ve Değerlendirme}

\section{Sosyo-Demografik Bilgiler}

Katılımcıların genel profilini ortaya koyan sosyo-demografik niteliklerine dair bazı bilgiler şöyledir.

Tablo 1: Derinlemesine Görüşme Yapılan Kişilerin Bilgileri' ${ }^{17}$

\begin{tabular}{|l|l|l|l|l|l|}
\hline Görüşmeci & $\begin{array}{l}\text { Yaşadıkları } \\
\text { Yer }\end{array}$ & Cinsiyet & Yaş & Ĕgitim durumu & Meslek \\
\hline Olga & İstanbul & Kadın & 63 & Yüksekokul & Kargo şirketinde çalışmaktadır. \\
\hline Lila & İstanbul & Kadın & 47 & Yüksekokul & $\begin{array}{l}\text { İnşaat sektöründe santralde } \\
\text { çalışmaktadır. }\end{array}$ \\
\hline Sofia & İzmir & Kadın & 46 & Üniversite & Çalışmamaktadır. \\
\hline Nadya & İstanbul & Kadın & 46 & Yüksekokul & Çalışmamaktadır. \\
\hline Luciana & İstanbul & Kadın & 44 & Üniversite & Çalışmamaktadır. \\
\hline Natalia & İstanbul & Kadın & 43 & Üniversite & Eşi ile birlikte cafe işletmektedir. \\
\hline Nina & İstanbul & Kadın & 40 & Lise & Kurye \\
\hline Ludmila & İstanbul & Kadın & 39 & Üniversite & Pazarlama sorumlusu \\
\hline Galina & İstanbul & Kadın & 36 & Lise & Çalışmamaktadır. \\
\hline Marianna & İstanbul & Kadın & 35 & Üniversite & Çalışmamaktadır. \\
\hline Anya & İstanbul & Kadın & 31 & Lise & Çalışmamaktadır. \\
\hline
\end{tabular}

Araştırma kapsamında Türkiye'de yaşayan yaşları 31 ile 63 arasında değişen 11 Gagauz Kadın ile derinlemesine görüşme yapılmışır. Her yaş grubundan katılımcı ile görüşülmeye çalışılmıştır. Farklı yaş gruplarıyla görüşmenin verileri zenginleştirileceği düşünülmüştür. Katılımcıların kadınlardan

17 İsimler, katılımcıların kendi isimleri olmayıp Gagauzlarda kullanılan farklı isimlerle değiştirilmiştir. 


\section{SAĞLAM, Nesibe Ayşe (2021). “Göçmenlikten Yerleşikliliğe: Gagauz Kadınların Evlilik Deneyimleri”, Mavi Atlas, 9(1): 250-274}

oluşması, Gagauzlardan çoğunluk olarak kadınların Türkiye’ye çalışmak için gelmesi ve Türkiyelilerle evlenmesiyle ilgilidir. Kadınların eğitim durumlarına bakıldığında eğitim seviyelerinin yüksek olduğu görülmüştür. Görüşülen kişilerden en düşük eğitim seviyesine sahip olan lise düzeyinde olmakla birlikte üniversite mezunları çoğunluğu oluşturmaktadır. Kadınların evlilikleri incelendiği için eşlerinin eğitim bilgileri de öğrenilmiştir. Eşlerinin ise ilkokul-ortaokul-lise-üniversite düzeylerinde eğitim aldıkları görülmüştür. Bazı kadınların eşleri ile eğitim durumları birbirlerine uyumlu iken bazıları birbirlerinden oldukça farklıdır. Buradan ve kadınların eş seçimleri ile ilgili söylemlerinden eğitim seviyelerinin evliliklerinde belirleyici olmadığ1 anlaşılmıştır. ${ }^{18}$ Onlar, eşleriyle evlenmelerini belirleyen temel etkenlerin genellikle sevgi, kişilikleri ve yaşam tarzlarının uyuşması olduğunu söylemişlerdir. Kadınların 5'i farklı iş sektörlerinde çalışırken 6'sı çalışmamaktadır. Çalışmayanlar, çocukları olduğunu ve onların yetiştirilmesiyle ilgilendiklerini söylemişlerdir. Katılımcılardan sekizi 1-2-4 çocuklu, biri çocuksuz olup ikisinin eski eşinden çocuğu bulunmaktadır. Bu evliliği gerçekleştiren kadınlardan 6'sının ve erkeklerin 4'ünün ikinci evliliğidir. 5 çiftin ise ilk evlilikleridir. Dolayısıyla eski eşlerinden çocuklarıyla birlikte yaşayan aileler de vardır. Bu çalışmada çocukların yetiştirilme ve kimliklenme durumu incelenirken sadece Gagauz-Türkiyeli evliliklerden olanların durumuna dair değerlendirme yapılmıştır. Katılımcıların eşleri genellikle marangoz, elektrikçi, ayakkabıcı, güvenlik görevlisi, mühendis gibi farklı iş sektörlerinde çalışmaktadır. Kadınların eşleri, Türkiye'nin değişik illerindendir. ${ }^{19}$ Ancak çoğunlukla eşleriyle İstanbul, İzmir, Ankara, Antalya gibi büyük kentlerde tanışmışlardır. Katılımcıların hepsi Türk vatandaşı olmuşlardır. Bazıları evlendikten üç yıl sonra eşleri aracıllı̆ıyla vatandaş olurken bazıları evlilikleri öncesinde Türk vatandaşı olmuşlardır.

\section{Göçmenlikle Başlayan Evlilikle Süreklilik Kazanan Yeni Gündelik Yaşam}

Gruplar arası evlilik literatüründe, ulus-aşırı evlilik göçü ve göçmenler-yerliler arasında gerçekleşen evlilikler önemli bir yere sahiptir. Genellikle ulus-aşırı evlilik göçlerinde göçü gerçekleştiren bağımlı bireylerin, gittikleri yeni toplumu tanıması, o toplumun dini, dilsel, kültürel değerleri ve yaşam tarzı ile etkileşime geçmesi ister istemez eşleri aracıllğıyla evlilik deneyimleriyle ilişkili olarak gerçekleşmektedir. Oysa bir ülkeye çalışmak, eğitim almak, daha refah bir yaşam düzeyine ulaşmak vb. nedenlerle göç edip süreç içerisinde ev sahibi konumundaki çoğunluk gruptan biriyle evlilik gerçekleştiren bireylerin, evlilik öncesinde söz konusu yeni toplumun dini, dilsel, kültürel değerleri ve yaşam tarzını tanıma ve bazı değerlerini içselleştirme ihtimali vardır. Gagauz kadınlar da Türkiye’ye öncelikle emek göçüyle gelen, çoğu 1-3-5-10 yıl çalışma yaşamının ardından Türkiyeli eşleriyle tanışıp arkadaşlıkları sonrasında evlenmişlerdir. Dolayısıyla çoğu eşleriyle evlilikleri öncesinde Türk toplumunun dini, dilsel, kültürel değerlerini ve yaşam tarzını tanımıştır. Genellikle onlar, evlilik öncesinde -anadillerinin Türkçeye benzer olması etkili olsa da- Türkçeyi düzgün bir şekilde anlamakta

\footnotetext{
18 "Bizde mutlu bir evlilik yapmak için aynı sosyal statü ve aynı eğitim seviyeye sahip olmalı derler ama bizde fark yaratan herhangi bir şey yok. Ben şunu da belirtmek isterim aslında baktığında ben 5 yıl üniversite okudum, burada lise mezunu biriyle evlendim, konuşulan konular veya algıladığım benim bakış açılarım farklı olabiliyor ama yine de uyumluyuz yani. Ben kendimi geliştirmeye açık bir insanım, öğretmen olduğumdan değil sadece kendi mesleğimle ilgili değil, gelişmeyi hedefleyen bir insanım. Eşim de üniversite mezunu olmamasına rağmen gerçekten farklı, çok yaratıcı biridir, insanı etkiler, bir şeyden bir şey yaratabiliyor sadece bir diplomaya sahip değil, bir kağıdı almak da hedef olmamalı. Kendine ait bir şey bulması kendini bir işe yakın hissetmesi, vermesi, mutlu olması, menajerlik yapt1, Serdar Ortaç ve Ceylanla. Okumayı çok sever kitapları çoktur" (Ludmila, Hristiyan, 39). "Evliliğim temel etken sevgi, eşimi çok seviyorum” (Sofia, Hristiyan, 46). "Biz birbirimizi gördük, beğendik. Eşim bizim evin orda bir yerde çalışıyordu arada bakışıyorduk sonra konuştuk öyle bir ay içinde de evlendik düşün yani” (Anya, Müslüman, 31).

$19 \mathrm{Bu}$ nedenle onları; farklı etnik, dini aidiyetlere sahip olma durumlarını da içine alacak şekilde Türkiyeli olarak tanımlamaktayız.
} 


\section{SAĞLAM, Nesibe Ayşe (2021). “Göçmenlikten Yerleşikliliğe: Gagauz Kadınların Evlilik Deneyimleri”, Mavi Atlas, 9(1): 250-274}

ve konuşmakta, Türk toplumunun dini-kültürel değerlerini ve yaşam tarzını benimsememiş olsa bile öğrenmiş ve aşinalık kazanmış olmaktadır. Buna rağmen evlilik daha derinlikli ve uzun süreli bir sosyal ilişki biçimi olduğu için bu süreçle birlikte bireylerin yaşamları önemli ölçüde değişim gösterebilmektedir. Bu çalışmada da katılımcılara "Evlilik öncesi ve sonrası yaşamınızdan bahseder misiniz? Evlilik deneyiminizle gündelik yaşamınızda neler değişti, nasıl yaşayan, nasıl düşünen biri oldunuz?" dediğimizde onlar gündelik yaşamlarındaki değişimlerin evlilikleriyle değil göçmenlik ve iş süreçleriyle başladığını anlatmışlardır:

Evlenmeden önce değil de Türkiye’ye gelmeden önce ben dinime çok düşkün bir insandım. Mesela ben Moldova'dayken her hafta sonu manastıra giderdim. Lise'de çalıştığım dönemde bile en az ayda 2 kez manastıra giderdim, dua ederdim. Orda kalmak için orda yer var, o ana yoldan manastıra kadar yürümen gerekiyor, Allah’a yürüme gibi. Ben de bazen Cuma'dan oraya gidiyordum sakin bir ortamda kitap okuma ortamım oluyordu. Dua ediyordum, huzur buluyordum ve sik sik bunu yapan bir insandım. Burada da kiliseye gidiyorum ama her hafta sonu çok imkânım olmuyor şimdi işten dolayı. Çünkü yurt dişına gittiğimde Pazar sabah dönüyorum, 12'de ibadet bitiyor ama en son 2 hafta önce Cuma bizim bir dini bayramımızdı ona gittim (Ludmila, Hristiyan, 39).

Ben tam kendimi bilme çağımda 18 yaşımda Türkiye’ye geldim çalışmak için. İş konusunda çalışma konusunda yani maddi açısından kendimi her zaman Türkiye'de görüyorum. Moldova'da eğer maddi açıdan durum iyi olsaydı, orda yaşamak isterdim. Orda insanlar çalışıyorlar ama yılbaşı var paskalya var, yılbaşından sonra böyle evleri geziyorlar yani bayram açısından her gün neredeyse bayram, kuru bir hayat değil böyle. Burada bunların hiçbirisini yapamiyorsun (Galina, Hristiyan, 36).

Türkiye'de yaşayınca ister istemez hayatın değişiyor. Gagauzya'da yaşasaydım kiliseye giderdim, yılbaşını biliyorsun bizde eski yılbaşı kutlanıyor, noel kutlanıyor, herkes birbirine geziyor, çocuklar geziyor, şeker topluyorlar, şey yapıyorlar hani orda yaşasaydım tabiî ki ben şeker de alırdım şey de yapardım, ona göre yaşardık ama burada öyle bir şey yok (Lila, Hristiyan, 47).

Kadınlar, gündelik yaşamlarının değişiminin genellikle Türkiye’ye göç süreçleriyle başladığını ve bu değişimi Gagauzya ile Türkiye'deki yaşamın farklılı̆̆ıla açıklamışlardır. Zaten "hareket ve göç karmaşık bir dönüşümü içermektedir" (Chambers, 2014: 47). Buraya göçleriyle başlayan, evlilik deneyimiyle devam eden bu değişimin boyutu ve içeriği genellikle bireylere ve evlendikleri kişilere göre de farklılaşarak evlilikleriyle birlikte devam etmiştir. Bazı kadınlar, evlilik deneyimiyle gündelik yaşamlarının büyük ölçüde değiştiğini söylerken bazıları kısmi bir değişim yaşadıklarını söylemiştir. Galina Hanım, evlendiğinde gündelik yaşamının maddi ve manevi yönlerden büyük ölçüde değiştiğini şöyle anlatmıştır:

Ben Türkiye'ye 2002'de geldim ve genelde biz zengin ailelerde çalıştığımız için hatta son 1 yılda ben çok zengin bir amcada çalıştım. Yokluğu(fakirlik) ben tabiî ki gördüm, memlekette de gördüm ama Türkleri ben çok farklı görüyordum. Biz zengin hep o çevrenin içerisinde olduğumuz için normal Türk halkı nasıl yaşar, ne kadar maaş alır, Tük kültürü vs. sadece dışarıdan duyabiliyorsun ama çok fazla detaylı içine girmemiştim. Eşimle evlendikten sonra işte o zaman öğrenmeye başladım. Büyük bir sıkıntı yaşadım çünkü benim için tamamen hayatım değişti. Eşimin ailesiyle birlikte yaşamaya başladık. Ekonomik olarak değişti mesela bana dediler alısveriş için Carrefour gibi yerler yok, Bim veya Şok gibi yerler olabilir ben şok oldum. Bide her şeyi sayarak tartarak yapmamı istediler. Ben de son yıllarda buna alışık olmadığım için benim için şok oldu, hasta oldum. Bıraksam gitsem aklımda tabii vardı bırakıp gitmek de. Ama sonra hamile de olunca sonra dedim yaşım 30. Ama eşimin ailesinin yanında yaşıyorduk ev ev üstüne 


\section{SAĞLAM, Nesibe Ayşe (2021). “Göçmenlikten Yerleşikliliğe: Gagauz Kadınların Evlilik Deneyimleri”, Mavi Atlas, 9(1): 250-274}

orda büyük sıkıntı yaşadım hatta ondan sonra dayanamayıp bıraktım gittim. Aldım çocuğu memleketime gittim, ya ayrı bir evimiz olacak ya da akrabalardan uzak olacağı dedim. Sonra İstanbul'a gelmeye karar verdik ve tekrar birleştik. Sonra evlenmeden önce tabii daha özgürdüm, her yönden, maddi açıdan elim daha açıktı, o zamanları özlüyorum. Evlendikten sonra elim ayağım bağlandı. Çocuk mocuk karıştım hiç benlik değil yani öyle diyeyim. Ama olan durumu kabul etmeye çalışıyorum o şekilde. Sonra bizde özel günler çok önemlidir. Mesela doğum günleri olur, ben mesela eşimi başta buna çok şey yapiyordum, sevgililer günü hediye alıyordum, yılbaşı hediye alıyordum, doğum günü hediye alıyordum vs. karşıda bu mesela yoktu. Ama ben de artık bıraktım yapmıyorum ben bu şekilde yaparak onu alıştırmak istedim ama olmadi (Galina, Hristiyan, 36).

Bir başka katılımc ${ }^{20}$, evlenmesiyle gündelik yaşamının değiştiğini ancak asıl değişimin -daha önce bir süre Rusya ve ABD'de yaşayan biri- Türkiye'de yaşamaya başlamalarıyla gerçekleştiğini şöyle anlatmaktadir:

Ee tabi kıyafetime bile karışıyor yani eşim, her şey değişiyor. Yaşam tarzı anlamında sıkıntı yaşıyoruz. Evet, yani şöyle, yurt dışındayken eşim benim şortuma karışmıyordu. Türkiye'ye yerleştikten sonra şortla ben sokağa çıkamadım. Hani ne bileyim, ben Rusya'da, Amerika'da şortla gezebiliyordum. Türkiye'ye geldikten sonra şortla gezemedim, ha kapri pantolon giyerim. Ama böyle kısa şortla yok. Çevreden de olabilir. Aslında ailesi deseniz ailesi de çok öyle değil. Benim kayınvalidem 70 yaşında tayt giyer. Taytın üstüne bir şey giyer. Türkiye'de biraz kıyafet konusunda şey yapmaya başladı. Sonra Amerika'da bira içebiliyorduk, ağır içecekler falan hiçbir zaman içmiyorduk. Ama Amerika da arkadaşlarımız geldiğinde falan bira alıyorduk. Rusya'da da böyle işte, orda bir de tuzlu balık var ya balığın yanında bira işte arkadaşlarımız geliyordu, misafirler o zaman alırdık. Ama Türkiye'de içkiyi kesinlikle eve sokmayı bile yasakladı. Birayı bile kaldırdı. Kendi de içmiyor, eve de almıyor. Bir de camiye gidiyor, orada camiye gitmiyordu. Camiye mesela herkes gidiyor ya, işyerinde de gidiyor ya. Bir de galiba Türkiye'de olduğu için daha böyle bir şey hissediyor. Yurt dışında böyle şeyler yoktu. 9 senedir Türkiye'deyiz, 9 sene de Amerika'da yaşadık, Amerika'daki adamla Türkiye'deki adam bambaşka yaşam tarzı açısından. Dediğim gibi çocuklar büyür bir gün, gider miyiz tekrar, değişir mi? onu bilemem ama Türkiye de bu şekilde (Lila, Hristiyan, 47).

Lila Hanım, gündelik yaşamında giyim tarzı, yeme-içme pratikleri ile ilgili eşinin kısıtlamaları nedeniyle değişim yaşadığını ve bunların Türkiye'de yaşamaya başlamalarıyla eşinin Müslümanlığa daha düşkün olmasıyla gerçekleştiğini söylemektedir. Bu durumun aralarında çatışmaya neden olduğunu dile getirmektedir.

Nadya Hanım ise evlilik süreciyle gündelik yaşamındaki dini-kültürel ritüeller, yeme-içme, dil pratiklerindeki değişimleri kapsamlı bir şekilde anlatmakta ancak bu değişiklikleri içselleştirmediğini ve kendi kimliğini koruduğunu vurgulamaktadır:

Evlenmeden önce noel, paskalya, doğum günleri benim için çok önemliydi ancak evlendikten sonra pek kutlamıyorum. Evlenmeden önce de çok sık kiliseye gitmezdim, evlendikten sonra da öyle. Yöresel yemeklerimizi seviyorum ancak çoğunlukla malzemelerini bulamadığım için yapamıorum. Evlenmeden önce Rusça-Gagauzca konuşurdum ancak şimdi neredeyse ailem dışında kimseyle Rusça-Gagauzca konuşmuyorum. Dolayısıyla evlendikten sonra yaşam tarzımın bir boyutta değiştiğini söyleyebilirim. Yalnız kendi kültürümü de yaşayabiliyorum.

${ }^{20}$ Lila Hanım, eşiyle Türkiye'de tanışıp evlenmiş sonra Rusya ve Amerika'da yaşamışlar, ardından tekrar Türkiye'de yaşamaya başlamışlardır. 


\section{SAĞLAM, Nesibe Ayşe (2021). “Göçmenlikten Yerleşikliliğe: Gagauz Kadınların Evlilik Deneyimleri”, Mavi Atlas, 9(1): 250-274}

Burada her türlü kutlama ve bayramlara katılıyorsam da kendi hayatıma onları taşımadım (ramazan ve kurban bayramlarını kutlarız). Hep Gagauz kaldım (Nadya, Hristiyan, 46).

Buradaki katılımcıların söylemlerine ve genellikle göçmenlerin yerlilerle olan evliliklerine bakıldığında göçmen kişilerin, özellikle farklı etnik, dini gruptan biri ile evleniyorsa, çeşitli uyum süreçlerini deneyimlemek durumunda olduğu gibi bir alg1 söz konusudur. Bu süreçte sıklıkla evliliğin bağımlı katılımcısı olarak göçmenlerin/kadınların azami uyum göstermesi yönünde bir düşünce mevcuttur. Oysa bu çalışmaya katılanlardan yukarıdaki Gagauz kadınların söylemlerinin aksine çoğu kişi gündelik yaşam pratiklerinin pek değişmediğini ifade etmiştir:

Evlendikten sonra yaşamım pek değişmedi. Yortuları da, noeli de ailecek beraber kutluyoruz. Çocuklarım iki dil (Rusça-Türkçe) konuşuyor. Her şey güzel, sadece kiliseye az gidebiliyorum (Sofia, Hristiyan, 46).

Benim hayatım evlendikten sonra çok değişmedi. Mesela domuz ben bu eşimle evlenmeden önce de o hayvanı yemezdim, 20 senedir yemiyorum o benim mideme dokunuyor. Eşim de yemiyor, dedi bana onu ben yemem ben de ona dedim ben de yemiyorum zaten. Ama benim eski eşimden çocuklarım sadece alıskın onlar bizim sucuğa ben onlar için Laleli'den sucuk alıyorum sadece onlara yapıyorum. Sonra iş yerinde içki kullanmıyorum, satmıorum getirmiyorum da çünkü içki olursa kavga çıkar şey olur ben istemirem ben temiz para isterim, kirli istemerim. Tabi bizde şarap sürekli var, benim babam votka evde sürekli kendi yaper. Bizde devamlı var, $\mathrm{O}$ da bana gönderer ama benim eșim de ben de böyle az az bazı zamanlar içeriz. Böyle sarhoş olalım şey yapalım bu bizde yok. Böyle hani (Natalia, Hristiyan, 43).

Türkiye'ye geldikten sonra tabi yaşantım değişti ama evlenmeden önceki ve sonraki yaşamım arasında pek bir değişim olmadı (Olga, Müslüman,63).

Genellikle Gagauz kadınların; Gagauzca-Rusçanın yanı sıra Türkçe konuşmaları ve dinikültürel ritüeller ve törenlerini istedikleri kadar yerine getirememeleri, kiliseye eskisi kadar sık gidememeleri, yeme-içme-giyim alışkanlıkları gibi gündelik yaşam pratiklerinin değişimi Türkiye'ye emek göçüyle gelmeleriyle başlamış Türkiyeli eşleriyle evlenmeleriyle ise kişilere ve eşlerine göre boyutu ve içeriği değişiklik göstererek süreklilik kazanmıştır.

\section{Hristiyanlık Müslümanlık Arasında Bir Birliktelik}

Kadınların göçmenlik süreciyle başlayan evlilikleriyle devam eden gündelik yaşam pratikleri ile ilgili değişimlerin genellikle dini ve kültürel aidiyetleri ile ilgili olduğu görülmektedir. Gagauzlar ve Türkiyeliler, Türk kökenli ve Türk dilli olmalarına rağmen ayrı birer etnik gruptur. Aynı zamanda Türkiyeliler genellikle Müslüman, Gagauzlar ise Ortodoks Hristiyan olmalarıyla farklı dini aidiyetlere sahiplerdir. Dolayısıyla Gagauz kadınlar ve Türkiyeli erkeklerin evlilikleri hem etniler arası hem dinler arasıdır. ${ }^{21}$ Onlar dil, din, kültürleri ve bunlarla ilişkili olarak gündelik yaşamlarıyla farklılaşmaktadır. Barth'a göre (2001: 16-17) kişiler, kendi gruplarını -başkalarına karş1- tanımlarken öncelikli olarak kültürel farklılıklarını öne çıkarırlar. Ancak bu süreçte dikkate alınanlar objektif nitelikler olmayıp aktörlerin kendilerince önemli gördükleri sübjektif farklılıklardır. Bazen ise kişilerce algılanan sübjektif farklılıklar objektif nitelikler de olabilir. Bu çalışmada da Gagauz kadınlar, kendileri ve eşlerinin grupları

21 "Kadınlar, kendileri ve eşlerine dair tanımlamalarında eşleriyle hem etnik hem dini yönden farklı olduklarını belirtmişlerdir. Gagauz (Hristiyanım), Gagauz demek Gagauz kökenli olması, soyu Gagauzlardan gelen anlamındadır. Ben Gagauzca konuşabilen Gagauz Hristiyanım. Eşim Türk ve Müslüman (Türk demek Türkiye Türkü kökenli, misafirperver biri)" (Nadya, Hristiyan, 46). "Gagauz, ben Gagauzum diyorum şimdi Türküm diyemem her ne kadar Türk kökenler olsa da öyle geçmiyor. Gagauzum. Eşim Türk önce Türk derim tabiî ki sonra din Müslüman derim” (Marianna, Müslüman, 35). 


\section{SAĞLAM, Nesibe Ayşe (2021). “Göçmenlikten Yerleşikliliğe: Gagauz Kadınların Evlilik Deneyimleri”, Mavi Atlas, 9(1): 250-274}

arasında hissettikleri sübjektif temel farklılığın -aynı zamanda objektif farklılıkları olan- "din” olduğunu söylemişlerdir.

Din hariç temel değerler aynı (Lila, Hristiyan, 47).

İki toplumdaki her şey benziyor, fark yok sadece din farkı var, eşimle de pek farklı yönümüz yok (Sofia, Hristiyan, 46).

Dini farkl11k var, onun haricinde bilemiyorum ben sıkıntı yaşamadım, ben sayg1 duyuyorum onun isteklerine yaşam tarzına. $\mathrm{O}$ da bana pek karışmıyor o yüzden fazla bi sıkıntımız olmadı. Ben hep diyorum bizim kültürümüz ne oldu: Türk kültürü ve Gagauz kültürünün karışımı oldu (Marianna, Müslüman, 35).

Bazı kişiler ise din ile birlikte kültürel olarak da farklı olduklarını şöyle açıklamışlardır:

Bizim orası da her ne kadar din farklı olsa da eskiden Anadolu köyleri gibiydi, kadınların başı bizde de kapalıydı, işte kayınpederinin yanında yemek yiyemezdi, kültür de aynı gibiydi aslında. Ama biz ilk Türkiye'ye çalışmaya geldiğimizde insanların bize bakışı çok değişikti. Ben diyorum bunlar neden böyle bakıyor, o zaman kültürel olarak çok zorlanmıştım, sonra öğrendim okumayazma seviyesi düşükmüş burada, bizde komünist sistem mecbur herkes en az lise mezunudur ve herkes çalışmak durumundadır. Ben uzun yıllardır Laleli'de çalışıorum, hep krolar var. Yani kadına bakışları farklıydı, o zaman demiştim kültürel olarak da farklıymısız (Olga, Müslüman, 63).

Çalışkanlılık, meraklılık yönden yakınız bir de büyüklere sayg1 yönünden benziyoruz. Ama kültürel ve dini olarak iki toplum farklıyız. Gelenekler ve adetler çok farklı (çünkü gelenek ve adetler genel olarak kültür ve dine göre oluşmuş durumda) (Nadya, Hristiyan, 46).

Görüldüğü üzere bazıları her ne kadar kültür, gelenek-görenekler yönüyle Türkiyelilerle farklı olduklarına değinseler de genellikle temel farklılıklarının "din” olduğunu söylemişlerdir. Din onların eşlerinin ve kendi toplumları arasındaki sosyal sınır göstergesi olarak durmaktadır. ${ }^{22}$

Gordon (1967: 355), gruplar arası evliliklerdeki problemlerin farklı dinlere olan aidiyetten kaynaklandığının sıklıkla dile getirildiğini belirtir. Çünkü din, farklı ritüellere sahip olmaktan daha fazlasıdır, farklı dinler farklı değer ve standartları öğretmektedir. Bu çalışmaya katılan kadınların çoğu ise Gordon'un söyleminin aksini iddia etmektedir. Onlar eşleriyle dini farklılıklarının evlilikleri için bir sorun olmadığını, bu farklılı̆̆a hem kendilerinin hem eşlerinin saygı ve hoşgörüyle yaklaştığını ve bunun aralarında bir çatışma alanı olmadığını belirtmişlerdir. ${ }^{23}$

Din konusu hiç sorun olmadı bizde. Eşim de bana hiçbir şey söylemedi. O beni zorlamadı, yok Müslüman olacaksın yok şöyle demedi. Biz sevgili olduğumuzda Karaköy'de bizim kilise var, hristiyan kilisesi, eşim benimlen oraya beraber geliyordu, orda oturardı beni beklerdi. 2 sene oldu benim annem vefat etti. Eşim geldi, gördü bizim cenazeyi, bizde 3 gün bekletiyorlar ya ölüyü, benim eşim annemin başında 3 gün bekledi. Benim annemi çok severdi, kiliseye de geldi.

\footnotetext{
22 “Etnik grupların kendilerine özgü kriterlerle tanımlandıklarında bir süreklilik arz ettikleri görülür: Buna göre bu grupların sürekliliği sınırların korunmasına bağlıdır. Bu sınırları belirleyen kültürel unsurlar zaman içerisinde değişebilirler; grup üyelerinin kimliklerini ve grubun örgütsel yapısını belirleyen kültürel karakteristikler de değişebilir. Ancak, grup üyeleri ile grup dışında kalan kimseler arasında bir şekilde her zaman kutuplaşmaya varan farklılıkların olması sınırların sürekliliğinin teminatıdır. Etnik gruba aidiyeti belirleyen unsurlar “objektif” olarak nitelenen farklılıklar değil, toplumsal etkileşim sürecinde oluşan farklılıklardır" (Barth, 2001: 17-18).

23 Sadece bir kişi eşinin dinine karışmadığını ancak yaşam tarzı noktasında sorun yaşadıklarını anlatmıştır.
} 


\section{SAĞLAM, Nesibe Ayşe (2021). “Göçmenlikten Yerleşikliliğe: Gagauz Kadınların Evlilik Deneyimleri”, Mavi Atlas, 9(1): 250-274}

Bende onla beraber gezmeye gittiğimizde camileri falan aynı saygiyla giriyorum, kapalı giriyorum (Natalia, Hristiyan, 43).

Dini konularda tartışma olmaz. Bu konuda birbirimize anlayış gösteririz (Nadya, Hristiyan,46).

İkimiz de birbirimizin dinine saygılıyız. Eşim ikisine de çok saygılıdır. Benim de her dine, Allah’a saygim sonsuzdur (Nina, Hristiyan, 40).

Görüldüğü üzere Gagauz - Türkiyeli evliliklerde dinî değerlere sayg1 ve müdahale etmeme bir alternatif olarak tercih edilebilmektedir. Oysa bu tarz evliliklerde uyum için din değiştirmelerin yaşandığ1 da bilinmektedir. Türkiyeli erkekler ile evlenen Gagauz kadınlardan da din değiştirenler olmuştur. Ancak bu çalışmaya katılanlardan Müslüman olan üç kadın da Müslüman olmayı bireysel olarak kendilerinin istediklerini, eşlerinin din değiştirmeleri konusunda bir talepleri ve yönlendirmelerinin olmadığını söylemişlerdir ${ }^{24}$.

Ben Gagauzum benim özüm hiç değişmedi, eşimden de hiçbir zaman baskı görmedim, Biz Rus Komünist sistemine göre yetiştik, o zaman din yasaktı, ben hiçbir zaman dindar bir Hristiyan da olmadım, Müslüman da. Bir gün eşime Müslüman olmak istiyorum dedim. O da şaşırdı. Sen bilirsin ben karışmıyorum dedi. Hatta bak yarın bir tartışma olur şey olur sen beni Müslüman yaptın dersin, ben karışmıyorum, kendi kararın dedi. Sonra ben kendim Müslüman oldum. Ama Müslümanlığı yaşamadım, şimdi Müslüman olduğum için pişmanım ben neden? Çevremizde, dünyada hiç iyi işler yapan Müslüman yok çünkü, utanıyorum onlarla aynı dinden olmaktan. Ben kendimi Müslüman olarak da tanımlamıyorum çünkü yaşamıyorum (Olga, Müslüman, 63).

Ben kendim istedim Elhamdüllilah Müslümanım dedim. Eşim o konuyu açmadan ben kendim o konuyu açtım. O da sevindi. Ben nasıl bu konuyu açacağımı düşünürken sen bana bunu söyledin dedi ve sevindi o kadar. Bununla gurur duydu (Marianna, Müslüman, 35).

Ben evlenmeden önce Müslüman oldum. İlk ramazan oruç günümde eşimle tanıştım ve ilk iftarımı eşimle yaptım (Anya, Müslüman, 31).

Buradan ve başka dinler arası evlilikler üzerine yapılan araştırmalarda da problemlerin dini kaynaklı olduğu söyleminin günümüzde biraz değer kaybettiği görülmektedir (Balkanlığu, 2012). Çünkü modernleşme, sekülerleşme gibi toplumsal değişimlerle birlikte gündelik yaşamımızda dini değerlerin geri planda kalmasıla farklı dini aidiyetlere sahip bireylerin gündelik yaşam tarzları ve pratikleri benzeşmekte ve yakınlaşmaktadır (Kalmijn, 1991). Özellikle eşlerin dini bağlılıkları az ise söz konusu benzeşme daha çok yaşanmakta ve bu durum dini farklılı̆̆ın bir çatışma alanı olmamasını da etkilemektedir. Bu çalışmada da katılımcıların çoğu kendileri ve eşlerini dindar olarak tanımlamadıkları görülmektedir:

Ben hiçbir zaman dindar biri olmadım, eşim de öyle (Olga, Müslüman, 63).

Ben tam olarak Hristiyan da değilim. Hristiyan olarak doğmuşum ama SSCB'de, bizde o zamanlar din yasaktı. Anneannemden bazen şeyleri duyuyordum küçükken, yukarıda Allah var diye, bu yaşıma kadar inanmaya çalıştım. Ama bir türlü tam bir inanç gelmedi, ateistim desem daha doğru olur. Bunu eşim de, kayınvalidem de biliyorlar, din bir mecburiyet değil, kişiliğe özel bir şey. Eşim de fanatik değil, o da ben gibi meşhur söze; yukarıda Allah var'a inanmıyor. Biz

\footnotetext{
${ }^{24}$ Bu çalışmaya katılan sınırlı sayıda kişi olduğu için aksi örnekle karşılaşılmamış olunabilir. Zira Gagauzya'daki alan çalışması sırasında (Sağlam, 2018) Türkiye'de evlenen bizim Gagauzlardan din değiştirenler, başını örtenler, çarşafa bile girenler var. Bunların çoğunu buraya eşleri hiç göndermez, ailesiyle görüştürmez çok kadın var böyle şeklinde hikayeler dinlenmiştir.
} 


\section{SAĞLAM, Nesibe Ayşe (2021). “Göçmenlikten Yerleşikliliğe: Gagauz Kadınların Evlilik Deneyimleri”, Mavi Atlas, 9(1): 250-274}

değişik bir aileyiz, din konusunda farklı şeyler düşünüyoruz! Ben zaten çok fanatik dinci kocaya kesinlikle gitmezdim (Luciana, Ateist, 44).

Eşim pek dindar değil, ben de öyle tamam özel günlere, bayramlara dikkat ederiz ama her zaman böyle camiye, kiliseye gidelim yok öyle (Natalia, Hristiyan, 43).

Bazı kişiler ise eşlerini "dinine bağlı" olarak tanımlamalarına rağmen eşlerinin gündelik yaşamlarında tamamen din eksenli bir yaşam benimsemediği görülmektedir:

Eşim dinine bağlıdır. Normal Ramazanda hiç atlamaz oruçlarını, namazında niyazında tamam her gün kılmaz namaz, bazen de içiyor ama dinine bağlı yani (Anya, Müslüman, 31).

Dinine özen gösterir, şöyle Cuma günü herkes gibi camiye gider, ibadetini yerine getirir ama her gün günde beş defa değil (Ludmila, Hristiyan, 39).

Eşim dinine bağlı sayılır, ama bizde seviyeli bir şekilde, Ramazan ayında tamam saygı duyuyoruz ama eşim diğer aylarda içer de (Marianna, Müslüman, 35).

Eşlerin genellikle dinlerine çok bağlı bireyler olmamaları ve yaşamlarını dini bakış açıları çerçevesinde örgülemeyip, seküler bir yaşam sürmeleri onların gündelik yaşam tarzı ve pratiklerinin benzeşmesine ve farklılıklarına yükledikleri anlamın birlikteliklerine engel olacak boyutta olmadığını ortaya koymaktadır. Bu da evliliklerinin uyumlu bir şekilde sürmesini kolaylaştırmaktadır.

\section{Gagauzluk-Hristiyanlık ve Türklük-Müslümanlık Arasında Yeni Nesil}

Gruplar arası evliliklerde eșler arasında birbirlerinin farklılıklarına saygı ve hoşgörülü bir yaklaşım sergilenip uyum sağlanabilse de çocuklar olduğunda durum değişebilmektedir. Çocukların hangi dil, din ve kültürel unsurlara göre sosyalleşmesi ve yetiştirilmesi noktasında eşler arasında çatışmalar yaşanabilmektedir. Ancak bu durum yine eşlerin algıları, yaşama bakış açılarına göre değişiklik göstererek uyumlu bir şekilde de yönetilebilmektedir (Balkanlığlu, 2012: 169-171). Bu çalışmaya katılan Gagauz kadınların sekizinin Türkiyeli eşlerinden 1-2-4 arasında değişen çocukları vardır. Bir kişi çocuksuz olup, ikisinin de eski eşinden çocuğu olmakla birlikte üç kişinin Türkiyeli eşinden çocuğu bulunmamaktadır. Çocuklu olan katılımcılara eşleriyle çocuklarını yetiştirme konusunda sorun yaşayıp yaşamadıkları sorulmuştur. Kadınların bir kısmı eşlerinin kendilerine çocuk yetiştirme konusunda güvendiğini ve sorun yaşamadıklarını söylemiştir.

Ev içinde çocuk yetiştirmede \%80 benim sözüm geçer. Eşimin ailesi, annesi babası geldiği zaman mesela bir tek onlar karışıyorlarsa karışıyorlar. Onlar geldiğinde bir şeyler söylerler, ben de dinlerim ama yine bildiğimi yaparım yani. Eşim de onu öğrendi (Galina, Hristiyan, 36).

Eşim çocuk yetiştirme konusunda bana güveniyor, benim eğitimli olmam hem de bizim çocuk yetiştirme tarzımız çok hoşuna gidiyor, aşağı yukarı görüyor da o yüzden pek karışmıyor. $O$ yüzden ben ne dersem saygı duymaya çalısıyor, tamam sen haklısın der ve fazla tartışmaz (Marianna, Müslüman, 35).

Bir kısmı ise Türkiye'de yaşadıkları için çocuklarının Türk kültürüne göre yetiştiklerini söylemişlerdir. Bu kadınlar çocuklarının genellikle eşlerinin ait olduğu toplumun değerleriyle yetişmesini normal karşılamakta ve buna rıza göstermektedirler. Dolayısıyla eşleriyle sorun da yaşamamaktadırlar.

Türkiye'de yaşadığımız için çocuğumuz daha çok Türkiye Türk kültürüne göre yetişiyor (Nadya, Hristiyan, 46).

'Türkiye'de yaşadığımız için Türk kültürüyle büyüyorlar (Sofia, Hristiyan, 46). 


\section{SAĞLAM, Nesibe Ayşe (2021). “Göçmenlikten Yerleşikliliğe: Gagauz Kadınların Evlilik Deneyimleri”, Mavi Atlas, 9(1): 250-274}

Yüzeysel bir yaklaşımla bakıldığında çocukların Türkiye'de Türk toplumu içerisinde doğup büyüyüp yetiştikleri için genellikle Türk kültürüyle yetişmesi beklenmektedir. Oysa kadınların bazılan çocuklarının her iki kültür ile de yetiştiklerini söylemişlerdir.

Benim ya da eşimin kültürü şeklinde bir ayrımım yok doğru olana göre yetiştirmeye çalışıyoruz. Ama örneğin sünnet diyelim hem sağlık açısından iyi hem de bu toplumda yaşıyor, zorlanmaması gerek onu yaptırabiliriz (Nina, Hristiyan, 40).

Her iki kültürde de iyi olan şeyleri öğretiyoruz (Anya, Müslüman, 31).

Bu söylemler öylesine söylenmemiştir. Çünkü Gagauz kadınların da çocuklarının yetişmesi ve kimliğinin şekillenmesindeki etkisi yadsınmayacak boyuttadır. Kadınların çoğu evlendikten veya çocuğu olduktan sonra çalışmayıp, çocuğunu babaanne veya herhangi bir bakıcıya vermeyip kendisi büyütmekte ve yetiştirmektedir. Böylece onların çocuklarının yetişmesi ve kimliğinin şekillenmesinde etkisi büyüktür. Örneğin; çocuklarının iki dilli yetişmesinde kadınların etkisi net bir şekilde görülmektedir:

Evde Türkçe konuşuluyor ama ben çocuklarla Rusça da konuşuyorum. İki dili de bilmelerini istiyorum. Benim eşim de bunu destekliyor, iki dil her zaman iyi (Galina, Hristiyan, 36).

Ben çocuklarımla iki dilde konuşuyorum Rusça ve Türkçe ama tabii ağırlıklı Türkçe konuşuyoruz (Marianna, Müslüman, 35).

Evde çocuklarla hem Rusça hem Türkçe konuşuyorum (Sofia, Hristiyan, 46).

Eğitimli ve bilinçli anneler çocuklarıyla genellikle Türkçe'nin yanı sıra Rusça ${ }^{25}$ da konuşup öğretmektedirler. Çocukların iki dilli olarak kimliklenmeleri genellikle annenin bakış açısı ve yaklaşımına göre şekillenmektedir. Ayrıca kadınların çoğu genelde tatil dönemlerinde çocuklarını Gagauzya'ya götürerek çocuklarının aileleri ile kaynaşmasını ve Gagauz dil-din-kültürel ortamını ve gündelik yaşamını görmelerini ve deneyimlemelerini sağlamaktadırlar. Gagauz anneler, kendi etnik kimliğiyle de kimliklendirme çabalarının yanı sıra çocuklarının Türk toplumu içerisinde yaşadıkları için bu topluma göre de yetişmesini göz ardı etmemektedirler.

Gagauz kadınlar, eşleriyle çocuklarını genel dil ve kültür yönünden yetiştirme konusunda sorun yaşamamaktadır. Dini yönden bilinçlendirme ve yetiştirme konusunda ise çoğu çocuklarının şuanda küçük olduğu için problem yaşamadıklarını söylemişlerdir. Çocukları büyüdügünde de onların dinlerini kendilerinin seçeceklerini ifade etmişlerdir.

Maria, burada doğduğu için Müslüman (yani nüfus cüzdanında öyle). Şuanda din açısından burası ya da orası demiyoruz. Çocuk büyüyecek şimdi kendisini hangisine daha yakın hissedecekse onu seçecek. Biz zaten Müslüman veya Ortodoks din çerçevesi dişında onu yetiştirmemeye gayret ediyoruz. Hem burada hem orda önemli olan iyi bir insan olarak yetişmesi bizim de zaten amacimız o. Bu konu da şu an tartışlmıyor, görüşülmüyor. Şuan küçük mesela ama şeyi biliyor; baba sen Cuma günü camiye gideceksin dimi yine. Babası evet kızım gidecem dua edecem diyor. Mesela Moldovyadayken kilisenin yanından geçiyoruz anne bak Allah bizi görüyor, Allah kötü çocuklan cezalandırıyor. Ben kötü çocuk değilim ama diyor. Kilisenin de caminin de ne olduğunu biliyor. Her şeyi zaman gösterecek (Ludmila, Hristiyan, 39).

\footnotetext{
${ }^{25}$ Gagauz kadınların anadili Türk dillerinden Gagauzcadır. Ancak Gagauzlar, 1900’lu yılların başlarından itibaren Rus egemenliğinde yaşamışlardır. Özellikle SSCB döneminde eğitimin kitleselleşmesi ve Rusça olmasıyla Rusça Gagauzların ikinci dili hatta anadilinden biri olmuştur (Sağlam, 2019: 116, 118). Rusçanın işlevselliği nedeniyle de kadınlar çocuklarına Rusça öğretmektedir.
} 


\section{SAĞLAM, Nesibe Ayşe (2021). “Göçmenlikten Yerleşikliliğe: Gagauz Kadınların Evlilik Deneyimleri”, Mavi Atlas, 9(1): 250-274}

Kendileri tercih etsinler büyüyünce şuan biz herhangi bir dine göre yetiştirmiyoruz (Sofia, Hristiyan, 46).

$\mathrm{Bu}$ eşimden çocuğum yok ama eski eşimden 4 çocuğum var. Büyük oğlum Moskova'da çalışıyor, kızım ve 2 küçük çocuğum Türkiye'de. Kızım kendisi ayrı yaşıyor. 2 küçük oğlum ben ve eşimle yaşıyoruz. Küçükleri yanıma getirdim, İstanbul'da okuyorlar. Onları şimdi küçükten zorlamıyorum. Yok siz Hristiyansınız benim çocuklar büyünce kendi kararlarını kendileri verecek. Zaten kızım da İstanbul'da yaşıyor o Müslüman oldu. O kendi karar verdi, dedi ben istiyorum din değiştirmeyi. Geçen sene 1 ay oruç tuttu. Ben dedim karar sizin ben hiçbir şeye sizi zorlamadım. Ne seçiyorsunuz öyle de yaşıyorsunuz. Ben kendi çocuklarımı bile zorlamıyorum siz Hristiyansınız da böyle de yaşayacaksınız gibi. Ben onlara yol verdim, siz büyünce nasıl isterseniz onu seçiceniz. Zaten küçükler okulda Din Kültürü dersi görüyorlar eve gelip bana soruyorlar. Anne biz de böyle Müslümanlar da böyle diyorlar. Ben de evde var Rus dilinde sizin Kur'an, ben okuyorum önce meraktan aldım, farkı görmek istedim, hani ne fark var bizim dinden sizin dinde diye. Okudum sizin Kur'an'dan Rus dilinde ona göre çocuklara da anlatıyorum. Kur'an'da da böyle yazıyor bizim kitapta da böyle yazıyor. Allah bir farkı yok. Müslüman da olsan Hristiyan da olsan hepimiz Allah'ın yanına gidecez (Natalia, Hristiyan, 43).

Bazı kadınlar ise dini bir bakış açısıyla duruma yaklaşarak çocukların babasının dinini benimsemesi gerektiği düşüncesine sahiptirler. Bu nedenle çocuklarının Müslümanlı̆̆a göre yetişmesini doğal karşılamakta bunun doğruluğuna inanmaktadırlar.

Çocuğumuz Müslümanlığa göre yetişiyor (Nadya, Hristiyan,46).

Biz bunu konuştuk eşimle, çocuğumuzun babasının dinine göre yetişmesi doğru olandır ama sonrasında değiştirmek isterse tabiî ki kendi kararı (Nina, Hristiyan, 40).

$\mathrm{Bu}$ durum, Gagauz kadınların bazılarının ataerkil bir zihin yapısına sahip olduğunu göstermektedir. Onlar çocuklarının babalarının dini, dili, kültürü üzerine yetişmesi gerektiğinin normal olduğunu düşünmektedir. Dolayısıla çocuklarının yetişmesi ve kimliğinin şekillenmesi konusunda eşleriyle uyuşmazlık yaşamamaktadırlar.

Görüldüğü üzere Gagauz kadınlar, eşleriyle çocuk yetiştirme konusunda gerek dil-kültür gerek dini konularda ciddi bir çatışma yaşamamaktadır. Bazı kadınların çocuklarının eşlerinin dil-dinkültürüne uyum sağlamasını normal karşılamaları, bazılarının iki tarafın değerlerine uygun olarak yetiştirmeye çalışmaları bazılarının ise evrensel ahlak kurallarına göre yetiştirmeleri eşleriyle uyuşmazlık yaşamalarını engellemektedir. Ayrıca çoğunun çocuklarının dinlerini büyüdüklerinde kendilerinin seçeceğini söylemeleri Gagauz kadınların katı bir tavır sergilemediklerini ve çocuk yetiştirme konusunda eşleriyle orta yolu bulduklarını göstermektedir. Kadınların ve eşlerinin bu ılımlı yaklaşımları, onların genellikle dine göre yaşamlarını şekillendirmeyen seküler bireyler olmalarıyla ilgili olabilir. $^{26}$

${ }^{26}$ Sadece Lila Hanım, eşinin dinine bağlı birisi olduğunu ve çocuklarının Müslüman dinine göre yetişmesi konusunda 1srarcı olduğunu ve bu konuda çatışma yaşadıklarını anlatmıştır: "Çocuklarımız Müslüman. Araştırmacı: Kendi tercihleri mi? Nasıl kendi tercihleri Türkiye’ye ben onları kaç yaşında getirdim. 6 yaşında Türkiye’ye getirdim. Okula başladılar, direkt din dersleri görmeye başladılar. Yazın Kur'an'a gittiler. Seçme hakları da yoktu. Bir de çocuklar zaten doğduklarında eşim çok dinine düşü̈n bir insan olduğu için, çocukların isimlerini kulaklarına okumaları falan hepsini müslümanlığa uygun olarak yaptı yani. Hani şöyle söyleyeyim, çocukların farklı bir din şeçme şansı bile yoktu. Araştırmacı: Bu sizi üzdü mü? Yoo... $1 \mathrm{~mm}$ ama yine de evet. En büyük tartışma konumuz hepsi seçme şansı olmadan Müslüman olarak yetişti. Seçme şansları olmamalarına üzülüyorum. Araştırmacı: çocuklar sorguluyor mu annem böyle babam böyle? tabiî ki sorguluyorlar mesela bu yanlış kime göre neye göre yanlış, tartışma konusu oluyor. Sonra benim annem (Hristiyan) bize misafirliğe geldiği zaman 


\section{SAĞLAM, Nesibe Ayşe (2021). “Göçmenlikten Yerleşikliliğe: Gagauz Kadınların Evlilik Deneyimleri”, Mavi Atlas, 9(1): 250-274}

\section{Gagauz-Hristiyanlık ve Türklük-Müslümanlık Arasında Dokunan Yeni Kimlik}

Gagauz kadınların göçmenlikleriyle başlayan evlilik süreçleriyle devam eden çocuklarının oluşuyla birlikte artan Türk toplumunun kültür ve değerleriyle olan etkileşimleri ve ilişkileri onların kimliklerini ister istemez etkilemektedir. Zira "kimlikler, asla sabit değildir. Durum ve ortama göre yapılanır, yapı bozar ve yeni yapı kurarlar. Kesintisiz kımıldama halindedir; her sosyal değişim, kimlik olgusunu farklı bir biçimde tanımlamaya götürür” (Cuche, 2004: 129-130). Günümüzde tekil, sade bir kimliklenme biçiminin az olduğu bilinmektedir ki zaten göçmen olmak farklı kimliklerle tanışmayı ve etkileşimi beraberinde getiren bir durumdur. Bunun yanı sıra farklı gruptan biriyle evlenerek farklı dil, din ve kültürle uzun süreli bir etkileşim ister istemez çoklu kimliklenmeyi doğurur. Gagauz kadınlara "Şu anda kendinizi nasıl tanımlıyorsunuz?" diye sorduğumuzda bir kısmı kendilerini Gagauz olarak tanımlarken bir kısmı "Gagauz Türkü” şeklinde tanımlamıştır. Örneğin Gagauz-Türkü ifadesini Gagauzya'da yaşayanlar kullanmamaktadır. ${ }^{27}$ Türkiye'de yaşayan ve Türkiyeli erkeklerle evlenenlerden bazılarının kendilerini Gagauz-Türkü olarak tanımlamaları tekil kimlikten tireli kimliklere geçmeleri, onların kimlikleri yönüyle bir gözden geçirme ve etkileşim yaşadıklarını göstermektedir. “Türkiye'de yaşamanız ve Türkiyeli biriyle evlenmeniz yönüyle kendinizi Gagauz-Hristiyan, Türk-Müslüman kimliği arasında nerde görüyorsunuz? Kendinizi Türk toplumuna ait hissediyor musunuz?” diye soruları detaylandırdığımızda şunları söylemişlerdir:

Ben kendimi Gagauz Türkü hissediyorum. Eskiden Gagauzdum şimdi Gagauz Türkü gibi hissediyorum kendimi. Ben kendimi yabancı hissetmedim hiç, ben sanki hep burada yaşamışım gibi. Sadece eskiden kaçak olduğum için hep böyle polislerden korkuyordum, şimdi bile gördügümde eşime ay polis diyorum, eşim diyo sen artık vatandaşsın, bi anda böyle korku sarıyo içimi. Evlendikten sonra vatandaş olabiliyorsun ben de oldum. Ve kendimi Gagauz Türkü gibi hissediyorum (Anya, Müslüman, 31).

Ben Türk gibi hissediyorum kendimi. Ben fazla bir sıkıntı yaşamadığım için kültürlerimiz karışık olduğu için ben kesinlikle sorun yaşamadım. Bazen hatta beni Türk zannediyorlardı eşimin çevresinde de. Eşim ve kardeşi biz arka arkaya evlendik. Akrabalar bana bazen sizin yabancı gelin napiyor diye, eltimi bana soruyorlardi. Onu yabanc1, beni buradan zannediyorlardı; konuşma tarzım, oturmam kalkmam. Ben fazla bir sıkıntı yaşamadım kendimi de yabancı hissetmedim. Hatta yakın akrabaları eşimin sen de bizlerden gibisin, bir farkın yok diyorlar. Bunu çok duydum, duyuyorum hala da (Marianna, Müslüman, 35).

(Gülüyor) Evet buradanmışım sanki hep, kendimi Türkleşmiş gibi hissediyorum (Galina, Hristiyan, 36).

Çok şükür iyi bir aileye sahibim, kendimi yabancı hissetmiyorum, görümcemle kayınvalidemle alt üst oturuyoruz ve iyi anlaşıyoruz (Sofia, Hristiyan, 46).

Görüldüğü üzere bazı katılımcılar, kendilerini yabancı hissetmediklerini hatta artık bir kısmı kendilerini Gagauz Türkü bir kısmı Türk gibi hissettiklerini söylemektedir. Ancak bazı kişiler ise

\footnotetext{
sabah akşam duasını yapıyor. Çocukların odasında mesela kalıyor, orda duasını yapıyor. Eşim çocuklar onu gördüğü için etkilenir diye rahatsız oluyor. Şöyle eşime ben diyorum ben seninle evlenirken sen biliyordun annemin Hristiyan olduğunu, bir gün benim annem benim evime gelip de duasını yapamayacaksa o zaman benim ne işim var senin yanında. Hani bazı şeyleri ben nasıl kabulleniyorsam o da kabullenmeli. Aslında eşimin ailesi, ne annesi ne kız kardeşleri hiçbiri kapalı değil, dinle ilgisi yok ama eşim dinine düşkün" (Lila, Hristiyan, 47).

${ }^{27}$ Gagauzya'da yaşayanlar kendilerini direkt sadece Gagauz olarak tanımlamaktadır (Sağlam, 2019: 108-109).
} 


\section{SAĞLAM, Nesibe Ayşe (2021). “Göçmenlikten Yerleşikliliğe: Gagauz Kadınların Evlilik Deneyimleri”, Mavi Atlas, 9(1): 250-274}

aidiyetleri üzerine bir şey söylemeden uzun yıllardır burada yaşadıkları için alıştıklarını ve Türklere benzediklerini dile getirmiştir:

Birçok konuda sanki Türk gibi oluyorsun ister istemez farkına varmadan en basitinden bakış açısı bile benziyor zamanla (Nina, Hristiyan, 40).

Bazen ben bile şaşı11yorum kendime. Kıyafetine dikkat ediyorsun, ne bileyim konuşmana dikkat ediyorsun, ne bileyim Türkiye'de değișiyorsun. 9 sene bile beni değiștirdi ki ben daha önce Türkiye'de olsaydım daha da farklı olurdum. Misafirin ona göre geliyor, mesela bayram alışverişi yapiyorsun ve direk bu toplumda yaşananlara dahil oluyorsun (Lila, Hristiyan, 47).

Bazıları ise kendilerini buraya ait hissetmediklerini sadece alıştıklarını ifade etmişlerdir.

Ben kendi özümü korudum Gagauzum. Ayrıca burada kendimi yabanc1 hissetmiyorum ama burayı da tam olarak benimseyemedim, sadece alıştım (Olga, Müslüman, 63).

Kendimi buraya ait hissetmiyorum. Türkiye'de bu kadar sene yaşadıktan sonra bile bana evim gibi gelmiyor (Nadya, Hristiyan, 46).

Görüldüğü üzere kadınların aidiyet duygularının boyutuna göre yeni toplumsal kimlikle kimliklenme durumları da değişmektedir. Bazılarının kendisini Gagauz, bazılarının Gagauz Türkü veya Türk gibi hissetmesi ve tanımlaması söz konusu kimliklenmenin boyutlarını göstermektedir. Kadınların eşlerinin ait olduğu toplumun yanı sıra kendi toplumlarıyla da etkileşimleri ve ilişkilerinin devam etmesiyle $^{28}$ iki kültür, dil, din arasında yaşamaları ve onların kendi etnik, dini kimliklerini korumakla birlikte eşlerinin dini, dilsel, kültürel kimlikleriyle de kimliklenmeleri çoklu kimliklenme yaşadıklarını göstermektedir.

\section{Sonuç}

Bu çalışma, Türkiye’ye emek göçüyle -1990’lı yılların başlarından günümüze kadar- gelen ve süreç içerisinde Türkiyeli erkeklerle evlenen Gagauz kadınların evlilik sonrası gündelik yaşamları ve kimlik algıları ile ilgili değişimleri ve deneyimleri ortaya koymaktadır. Ayrıca gruplar arası olan bu evliliğin çocukların yetiştirilmesi ve kimliklenmesi konusuna kadınların ve eşlerinin nasıl bir yaklaşım sergilediklerini irdelemektedir. Gagauz kadınların gündelik yaşamlarındaki değişimler ilk olarak Türkiye'ye göç etmeleriyle başlamıştır. Türkiyeli eşleriyle evlenmeleriyle ise daha derinlikli ve uzun süreli bir sosyal ilişki biçiminin içine girmeleriyle hem göçmenlik sürecinde yaşadıkları değişimler geçicilikten kalıcı hale gelerek süreklilik kazanmış hem bu değişimlere yenileri eklenmiştir. Gündelik yaşamlarındaki değişimin boyutu ve içeriği genellikle bireylere ve eşlerine göre değişiklik göstermektedir. Ancak yine de kadınların gündelik yaşamlarındaki değişimler genel olarak şöyledir: kiliseye eskisi kadar sık gidememeleri, paskalya, noel, yılbaşı yortuları vb. dini-kültürel ritüel ve törenlerini istedikleri kadar kutlayamamaları, yeni olarak ramazan ve kurban bayramlarını kutlamaları,

${ }^{28}$ Gagauz kadınlar Türkiyeli eşleriyle evlilikleri sonrasında da her iki aile ve arkadaş çevresiyle ilişkilerinin eskisi gibi devam ettiğini söylemişlerdir: “Gagauzlardan genellikle ailem, akrabalarımla görüşüyorum. Türkiye'den eşimin ailesi, akrabalar1 ve arkadaşlarımızla görüşüyoruz. Burada yaşadığımız için tabiî ki görüştüğümüz kişiler daha çok Türklerden oluşuyor, sorun yok" (Nadya, Hristiyan, 46). "Gagauzya'dan ailemle görüşüyorum. Türkiye'de de Gagauz kızlarla görüşüyoruz (buraya çalışmaya gelenlerden arkadaşlarım çok), eşimin ailesi, akrabaları ve arkadaşlarıyla ilişkilerimiz aynen devam ediyor" (Svetlena, Hristiyan, 40). "Gagauzya'dan ailem, akrabalarımla görüşüyorum. Arkadaş olarak görüştüğüm en yakın arkadaşlarım Gagauzlardan da var Türklerden de var. Eşimin aile ve çevresiyle yakınız zaten sık sık görüşüyoruz, sorun yaşamadık hiç” (Marianna, Müslüman, 35). 


\section{SAĞLAM, Nesibe Ayşe (2021). “Göçmenlikten Yerleşikliliğe: Gagauz Kadınların Evlilik Deneyimleri”, Mavi Atlas, 9(1): 250-274}

yeme-içme alışkanlıklarının değişimi, giyimleri konusunda bazı eşlerin kısıllayıcı tavır sergilemeleri, Gagauzca-Rusçanın yanı sıra Türkçe konuşmaları vb. Bu değişimler, genellikle onların dini ve kültürel aidiyetleri ile ilgilidir. Zaten kadınlar, kendileri ve eşlerinin toplumlarının din ve kültür yönüyle farklilı̆ııa değinmekte ancak iki toplum arasındaki temel sosyal sınırın "din" olduğunu düşünmektedirler. Ancak bu sosyal sınırın evlilikleri için bir sorun olmadığını, buna hem kendilerinin hem eşlerinin saygı ve hoşgörüyle yaklaştı̆ı̆nı belirtmişlerdir. Katılımcılardan üç kişi Müslüman olarak eşinin dinini benimsemiştir ama bu eşlerinin yönlendirmesi olmaksızın kendi tercihleriyle gerçekleşmiştir. Ayrıca kadınlar, eşlerini hatta kendilerini dindar biri olarak tanımlamamaktadır. Eşlerin dini bağlılıklarının az olması dini farklılığın bir çatışma alanı olmamasını etkilemiş gibi gözükmektedir. Onların seküler bir yaşam sürmeleriyle eşleriyle gündelik yaşam tarzı ve pratiklerinin benzeşmesi ve yakın olmasıyla uyumlu bir birliktelik yürüttükleri düşünülmektedir.

Kadınların eşleriyle çocuk yetiştirme konusuna yaklaşımlarında da ılımlı bir tavır sergiledikleri görülmektedir. Onlar, eşleriyle çocukların dil ve kültürel yönden yetiştirmesi ve kimliklenmeleri konusunda sorun yaşamamaktadırlar. Dini yönden bilinçlendirme ve yetiştirme konusunda ise çoğu bir kişi haricinde- çocuklarının şuanda küçük olduğu için problem yaşamadıklarını söylemişlerdir. Çocukların yetiştirilmesi konusunda eşleriyle hiç mi sorun yaşamadıkları farklı sorularla irdelendiğinde; bazı kadınların şuanda Türk toplumu içerisinde yaşadıkları için çocuklarının babalarının dil ve kültür aidiyetlerine göre yetiştirilmesini normal karşılamaları, bazılarının her iki dil ve kültüre göre de yetiştirmeleri -örneğin kadınların çoğu çocuklarılla Türkçe'nin yanı sıra Rusça da konuşmaktadır. Tatillerde ailelerinin yaşadığı Gagauzya’ya götürerek ve Gagauz dil-din-kültürel ortamını ve gündelik yaşamını görmelerini ve deneyimlemelerini sağlamaktadırlar- dolayısıyla eşleriyle çatışma yaşamadıkları fark edilmiştir. Dini yönden ise bazılarının çocuklarının babasının dinine göre kimliklenmesine rıza göstermeleri bazılarının eşleriyle birlikte seküler bir yaşam benimsemiş olmaları ve çocuklarını genel ahlak kuralları çerçevesinde yetiştirip herhangi bir dini eğitim vermemeleri nedeniyle sorun yaşamadıkları görülmüştür. Katılımcıların geneli çocukları büyüdüğünde onların dinlerini kendilerinin seçmesi gerektiğini düşünmektedir. Netice olarak Gagauz kadınların çocuk yetiştirme konusunda eşleriyle bir denge sağladıkları görülmektedir. Eşlerin birbirlerinin dini farklılıklarına olduğu gibi çocuk yetiştirme konusunda da katı bir tutum sergilemeyip uyum sağlayabilmeleri onların genellikle dinlerine göre yaşamlarını şekillendirmeyen seküler bireyler olmalarıyla ilgili olduğu düşünülmektedir.

Gagauz kadınların göçmenlik süreci ve evlilik ilişkileriyle birlikte Türk toplumunun kültür ve değerleriyle uzun süreli etkileşimleri onların kimliklerini de etkilemiştir. Kadınların şuanda bazısı kendisini Gagauz, bazısı Gagauz Türkü bazıları da Türk gibi hissetmektedir. Bu tanımlamaların kendilerini Türk toplumuna ait hissedip hissetmeme durumlarına göre değiştiği fark edilmiştir. Türkiyeli erkeklerle evlenen Gagauz kadınların gündelik yaşam pratikleri ve kimliklerindeki değişim ve bu değişimlere uyumları, göçmen kadınların ev sahibi topluma entegrasyonuna bir örnek oluşturması açısından önemlidir. Zira 2-24 yıl arasında değişen uzun bir birlikteliği, çoğu çocuklu olmakla birlikte başarabilmişlerdir. Türkiyeli eşleriyle her ne kadar aynı etnik köken ve dil grubuna sahip olsalar da yine de farklı bir dil, din ve kültürel kimlikten biriyle birliktelik yaşamaktadırlar. Ve çoğu kadın kısa bir sürede bu dil, din ve kültürü anlayarak o toplumun gündelik yaşamına entegre ve adapte olmuş/olmaktadır. Onların iyi derecede Türkçe bilmeleri, kültürü, gelenek ve görenekleri kısa sürede öğrenmeleri toplumsal kabullerini hızlandırmıştır. Gagauz kadınların adaptasyon becerileri, eşlerine ve Türk toplumuna tümüyle uyum sağlama anlamında kullanılmamaktadır. Onların bu becerisi kendi din, dil ve kültürel değerlerini korumayı da içeren yaklaşımlarından kaynaklanmaktadır. Örneğin; bu çalsşmaya katılan 11 kişiden 3'ü kendi istekleriyle din değiştirerek Müslüman olmuş, diğgerleri Hristiyan 


\section{SAĞLAM, Nesibe Ayşe (2021). “Göçmenlikten Yerleşikliliğe: Gagauz Kadınların Evlilik Deneyimleri”, Mavi Atlas, 9(1): 250-274}

kimliklerini devam ettirmektedir. Hristiyan olanlar her ne kadar kendilerini pek dindar tanımlamasalar da Hristiyanlığa özgü anma günlerinden (Paskalya, Noel) en önemlilerini aile içerisinde kutlamakta ve sık olmasa da özel günlerde kiliselere gitmektedirler. ${ }^{29}$ Ayrıca kendi aile ve sosyal çevreleriyle ilişkilerini devam ettirmekte ve Gagauzların düzenledikleri dini-kültürel etkinliklere imkânları olduğunda katılmaktadırlar. Dolayısıyla onlar Türk toplumuyla etkileşimlerinin yanı sıra kendi toplumlarıyla da etkileşimleri ve ilişkilerinin devam etmesiyle hem kendi kimliklerini, sosyal sınırlarını korumakta hem de yeni toplumsal kimlikle de kimliklenerek yaşamaları uyumlu bir evlilik sürdürmelerini sağlamaktadır.

\section{Kaynakça}

AKALIN, Ayşe (2000). “'Yukandakiler-Aşağıdakiler’ İstanbuldaki Güvenlikli Sitelerde Göçmen ve Ev Hizmetlisi İstihdamı”, Türkiye’ye Uluslararası Göç (Toplumsal Koșullar-Bireysel Yaşamlar), ed. Barbara Pusch, Tomas Wilkoszewski, çev. Mutlu Çomak-Özbatır, İstanbul: Kitap Yayınevi.

AKSOY, Bülent (2016). "Post Sovyet Dönemde Jeopolitik Açıdan Gagauz Nüfusu", Hamidullah Suphi ve Gagauðlar, ed. Mehmet Şahingöz ve Alper Alp, ss.245-255, Ankara: Türk Yurdu Yayınları.

ANDERSON, Michael (1999). "Children In-Between: Constructing Identities in the Bicultural

Family”, $\quad$ Erişim $\quad$ Tarihi: 06.08.2020,
(https://www.jstor.org/stable/2660960?seq=1\#metadata_info_tab_contents).

ASPINALL, Peter, J. \& Miri SONG, (2013). "Mixed Race Identities”, Erişim Tarihi: 26.07.2020,(https://books.google.com.tr/books?hl=tr\&lr=\&id=hRA0AAAAQBAJ\&oi=fnd\&pg=P $\mathrm{P} 1 \& \mathrm{dq}=$ miri + song + mixed\&ots $=$ ZiN5q2phfx\&sig=USbmfAq3zvbuD_uWnGzp023ebio\&redir_esc ${ }_{\mathrm{y}} \#_{\mathrm{v}}=$ onepage $\& \mathrm{q}=$ miri $\% 20$ song $\% 20$ mixed $\& \mathrm{f}=$ false $)$.

BALKANLIOĞLU, Mehmet Ali (2012). “Alevi-Sünni Evliliklerinin Aile İlişkileri ile Çocuk Yetiştirme Üzerine Etkileri ve Sosyal Damgalama”, Erişim Tarihi: 04.05.2020, (https: / scholar.google.com/scholar?hl=tr\&as_sdt=0\%2C5\&q=AleviS $\% \mathrm{C} 3 \% \mathrm{BCnni}+$ Evliliklerinin

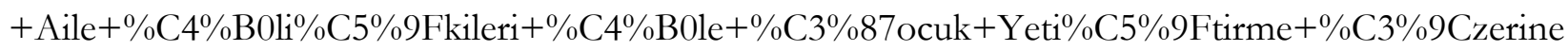
+ Etkileri+ve+Sosyal+Damgalama\&btnG=).

CANBAZOĞLU, Oya (2019). “Gagauz Yeri Dünden Bugüne”, Erişim Tarihi: 01.05.2019, (http://www.gagauzya.com/gazete/Gokoguz4.pdf).

CASTELS, Stephen \& Mark J. MILLER, (2008). Gögler Çağı: Modern Dünyada Uluslararası Göç Hareketleri, çev: Bülent Uğur Bal ve İbrahim Akbulut, İstanbul: İstanbul Bilgi Üniversitesi Yayınları.

\footnotetext{
29 "Noel, Paskalya, Yılbaşı da önemli bizim için, doğum günlerini kutlarız hep. Doğum günü kültürü eşimin ailesinde yoktu ben aileye girdiğimden sonra biraz biraz kutlamaya başladık. Ben anneye, babaya, kardeşlerine, yeğenlerine çiçek olsun, herkese sürpriz yaparım, pasta keseriz. Biraz alışkın değildiler böyle bir geleneksellik yoktu ailede. Bi de bu daha sık görüşmeye fırsata dönüştü aslında doğum günü kutlamaları, herkesi bir araya topluyoruz ortak bir etkinlik olmuş oluyor. Ayrıca sizin Ramazan, Kurban bayramlarını kutluyoruz" (Ludmila, Hristiyan, 39). "Bizim bayramlar1 da kutluyoruz sizinkileri de kutluyoruz. Paskalya, Doğum Günleri, Yılbaşı, Kurban ve Ramazan Bayramı. Aynı saygıyla eşim bizim bayramları kutluyor ben de sizinkileri kutlerim. Paskalya bayramında devamlı paskalya çöreği yapıyoruz, yumurta boyuyoruz, benim eşim de çok beğeniyor" (Natalia, Hristiyan, 43). "Her müslüman bayramını (Türkiye'de kutlananları) ve Paskalya'yı, doğum günleri, yılbaşını kutlarız aile içinde” (Nadya, Hristiyan, 46).
} 
CHAMBERS, Iain., (2014). Gọ̈, Kültür, Kimlik, çev. İsmail Türkmen ve Mehmet Beşikçi, İstanbul: Ayrıntı Yayınları.

CHİRCIUU, Dimitri (2014). “Günümüzde Gagauz Yeri’nde Yaşanan Göçler ve Nedenleri”, Erişim Tarihi: 03.08.2016, (https://tehlikedekidiller.com/turkce/wp-content/uploads/DmitriCHIRCIU-G\%C3\%9CN\%C3\%9CM\%C3\%9CZDE-GAGAUZ-YER\%C4\%B0.pdf).

CRESWELL, John W. (2017). "Etnografik Desenler", Eğitim Araştırmaları Nicel ve Nitel Araştırmanın Planlanması, Yürütülmesi ve Değerlendirilmesi, çev. Seyda Çakır, İstanbul: Edam Yayınları.

CUCHE, Denys (2004). Sosyal Bilimlerde Kültür Kavramı, çev. Turgut Arnas, İstanbul: Bağlam Yayıncilik.

ÇATAK, Bilge Deniz (2015). "Mezhep Farklılıklarının Evli Çiftlerin İlişkileri Üzerindeki Etkileri: Berlin-İstanbul Örneği”, $\quad$ Erişim $\quad$ Tarihi: (https://scholar.google.com/scholar?hl=tr\&as_sdt=0\%2C $5 \& q=$ Mezhep + Farkl $\% C 4 \%$ B $11 \% C 4 \% B 1$ $\mathrm{klar} \% \mathrm{C} 4 \% \mathrm{~B} 1 \mathrm{n} \% \mathrm{C} 4 \% \mathrm{~B} 1 \mathrm{n}+$ Evli $+\% \mathrm{C} 3 \% 87$ iftlerin $+\% \mathrm{C} 4 \% \mathrm{~B} 0 \mathrm{li} \% \mathrm{C} 5 \% 9$ Fkileri $+\% \mathrm{C} 3 \% 9$ Czerindeki+ Etkileri\%3ABerlin-\%C4\%B0stanbul+\%C3\%96rne\%C4\%9Fi\&btnG=).

DEDEOĞLU, Saniye ve Çisel EKİZ GÖKMEN, (2011). Gọ̈ ve Sosyal Dışlanma-Türkiye’de Yabancı Gösmen Kadınlar, Ankara: Efil Yayınevi.

DENIZ, Ayla ve E. Murat ÖZGÜR, (2013). “Antalya’daki Rus Gelinler: Göçten Evliliğe, Evlilikten Göçe”, $\quad$ Erişim Tarihi: 04.05.2020, (https://www.researchgate.net/publication/272496198_Antalya'daki_Rus_Gelinler_Gocten_Evlilige _Evlilikten_Goce_The_Russian_Brides_in_Antalya_From_Migration_to_Marriage_from_Marriage_ to_Migration)

DEMIRDIREK, Hülya (2007). "New Modes of Capıtalıst Domınatıon: Transnatıonal Space Between Turkey and Moldova," Erişim Tarihi: 03.09.2016, (https://www.academia.edu/1278601/New_Modes_of_Capitalist_Domination_Transnational_Spac e_Between_Turkey_and_Moldova).

DRİBE, Martin \& Christer LUNDH, (2008). "Intermarriage and Immigrant Integration in Sweden: An Exploratory Analysis", Erişim Tarihi: 19.07.2020, (https://journals.sagepub.com/doi/abs/10.1177/0001699308097377).

ERTITT, Volkan (2019). Sekülerleşme Teorisi, Ankara: Liberte Yayınları.

ERTUĞRUL, Nejdet ve Olga RADOVA, Türkiye'de yaşayan Gagauzları anlatmaktadır: ErişimTarihi:18.02.2019,(https://www.facebook.com/watch/live/?v=222818945222961\&ref=watch _permalink).

GARCÍA, Dan Rodríguez (2008). "Socio-Cultural Dynamics in Intermarriage in Spain: Beyond Simplistic Notions of Hybridity”, Erişim 11.08.2020, (https://www.researchgate.net/publication/263088699_SocioCultural_Dynamics_in_Intermarriage_ in_Spain_Beyond_Simplistic_Notions_of_Hybridity). 
GARCÍA, Dan Rodríguez (2010). "Beyond Assimilation and Multiculturalism: A Critical Review of the Debate on Managing Diversity", Erişim Tarihi: 11.08.2020, (https://link.springer.com/article/10.1007/s12134-010-0140-x).

GÜLER, Ahmet; HALICIOĞLU, Mustafa Bülent ve Serkan TAŞĞIN (2013). Sosyal Bilimlerde Nitel Araștırma Yöntemleri, Ankara: Seçkin Yayınları.

GORDON, Albert I. (1967). Intermarriage: interfaith, interracial, interethnic, Boston: Beacon Press.

GÜNDÜZ HOŞGÖR, Ayşe \& Jeroen SMITH, (2002). "Intermarriage between Turks and Kurds in Contemporary Turkey Inter-ethnic Relations in an Urbanizing Environment", Erişim Tarihi:07.05.2020,(https://www.researchgate.net/publication/31412034_Intermarriage_between_Tu rks_and_Kurds_in_Contemporary_Turkey_Interethnic_Relations_in_an_Urbanizing_Environment).

KALMIjN, Matthijs (1991). "Shiftıng Boundaries: Trends in Religious and Educational Homogamy",

Erişim Tarihi: (https://www.jstor.org/stable/2096256?seq=1\#metadata_info_tab_contents).

KALMIjN, Matthijs (1998). "Intermarriage and Homogamy: Causes, Patterns, Trends", Erişim Tarihi: 07.05.2020, (https://www.annualreviews.org/doi/abs/10.1146/annurev.soc.24.1.395).

KARANFILL, Güllü (2015). "Gagauziyada Gagauz Dilinin Durumu," Erişim Tarihi: 12.08.2016, (http://eurasian.eurasianacademy.org/dergi//gagauziyada-gagauz-dilinindurumu201510.pdf).

KAŞKA, Selmin (2007). “Ev içi Hizmetlerin Küreselleşmesi ve Türkiye’deki Göçmen Kadınlar", Türkiye'de Yabancı Isş̧iler Uluslararası Göç, İsgücü ve Nüfus Hareketleri, der. Aylan Arı, ss.225240, İstanbul: Derin Yayınlar1.

KAŞKA, Selmin (2016). "Yeni Uluslararası Göç Hareketleri ve Türkiye'deki Moldovalı Kadın Hizmetçiler", $\quad$ Erişim $\quad$ Tarihi: 21.11.2017, (http://menadoc.bibliothek.unihalle.de/menalib/content/pageview/1876400).

KEOUGH, Leyla J. (2003). "Driven Women: Reconceptualızing The Traffic In Women In The Margins Of Europe Through The Case Of Gagauz Mobıle Domestıcs In Istanbul”, Erişim Tarihi:22.11.2017,(https://scholar.google.com/scholar?hl=tr\&as_sdt $=0 \% 2 \mathrm{C} 5 \& q=\mathrm{Dr} \% \mathrm{C} 4 \% \mathrm{~B} 1 \mathrm{ven}+$ Women $\% 3 \mathrm{~A}+$ Reconceptual $\% \mathrm{C} 4 \% \mathrm{~B} 1 \mathrm{z} \% \mathrm{C} 4 \% \mathrm{~B} 1 \mathrm{ng}+\mathrm{The}+$ Traff $\% \mathrm{C} 4 \% \mathrm{~B} 1 \mathrm{c}+\mathrm{In}+$ Women + In + The+ Marg $\% \mathrm{C} 4 \% \mathrm{~B} 1 \mathrm{~ns}+\mathrm{Of}+$ Europe + Through + The + Case + Of + Gagauz + Mob $\% \mathrm{C} 4 \% \mathrm{~B} 1 \mathrm{le}+\mathrm{Domest} \% \mathrm{C} 4$ $\% \mathrm{~B} 1 \mathrm{cs}+\mathrm{In}+$ Istanbul\&btnG $=$ ).

KOFMAN, Eleonore; PHIZACKLEA, Annie; RAGHURAM, Parvati \& Rosemary SALES, (2000). Gender and International Migration in Europe: Employment, Welfare, and Politics, Erişim Tarihi:11.07.2020,(https://books.google.com.tr/books?hl=tr\&lr=\&id=TKZ0iG49UNkC\&oi=fnd\& $\mathrm{pg}=\mathrm{PA} 1 \& \mathrm{dq}=$ gender + and + international + migration + in + europe: + employment,+ welfare + and + polit ics\&ots=9SRWhGm1Qv\&sig=mKqpGiwJxHoXQqZwkykb3QFHeb4\&redir_esc $=\mathrm{y} \# \mathrm{v}=$ onepage\&q $=$ gender $\% 20$ and $\% 20$ international $\% 20$ migration $\% 20$ in $\% 20$ europe $\% 3 \mathrm{~A} \% 20$ employment $\% 2 \mathrm{C} \% 20$ wel fare $\% 20$ and $\% 20$ politics \&f $=$ false). 
KÜMBETOĞLU, Belk1s (2017). Sosyolojide ve Antropolojide Niteliksel Yöntem ve Arasstrma, İstanbul: Bağlam Yayıncılık.

LORDOĞLU, Kuvvet (2007). "Çalışma Hayatımızda Yeni Yabancılar: Bir Araştırmanın Bazı Sonuçları ve Değerlendirmeler”, Türkiye'de Yabancı Isşciler Uluslararası Göç, İsgüüü ve Nüfus Hareketleri, Der. F. Aylan Ar1, ss. 83-121, İstanbul: Derin Yayınlar1

LUCASSEN, Leo \& Charlotte LAARMAN, (2009). "Immigration, Intermarriage and The Changing Face of Europe in The Post War Period," Erişim Tarihi: 17.05.2020, (https://www.sciencedirect.com/science/article/pii/S1081602X08000882).

MANASTIRLI, Serghei. “Turkiye’deki Gagauzları ve Gagauzlar Derneğini Anlattı” Erişim Tarihi: 27.06.2019, (https://www.facebook.com/gagauzdayanisma/videos/597229030776184).

ÖZATEŞLER ÜLKÜCAN, Gül; TÜRNÜKLÜ, Abbas; ERARSLAN İNGEÇ, Özge ve Sedef TULUM AKBULUT, (2019). "Gruplar Arası Temas ve Çapraz Evlilikler: İzmir'de Alevi-Sünni Evlilikleri”, $\quad$ Erişim $\quad$ Tarihi: 29.04 .2020 , (https://www.researchgate.net/publication/332427299_Gruplar_Arasi_Temas_ve_Capraz_Evlilikle r_Izmir'de_Alevi-Sunni_Evlilikleri_Intergroup_Contact_and_Intermarriages_AleviSunni_Marriages_in_Izmir).

PARK, Robert E. (1928). "Human Migration and the Marginal Man," Erişim Tarihi: 13.08.2020, (https://www.journals.uchicago.edu/doi/abs/10.1086/214592).

ROCKQUEMORE, Kerry, A. (1998). "Between Black and White Exploring The "Biracial" Experience,” Erişim Tarihi: 29.04.2020, (https://www.sciencedirect.com/science/article/abs/pii/S1090952499800448).

SAĞLAM, Nesibe Ayşe (2019). Post-Sovyet Süreçte Gagauz Kimliğinin Yeniden Üretilmesi Üzerine Sosyolojik Bir Araştırma, (Yayımlanmamış Doktora Tezi), İstanbul Üniversitesi Sosyal Bilimler Enstitüsü, İstanbul.

SCHNAPPER, Dominique (2005). Sosyoloji Düşüncesinin Özünde Öteki ile İlişki, çev. Ayşegül Sönmezay, İstanbul: İstanbul Bilgi Üniversitesi Yayınları.

TÖRNGREN, Sayaka Osanami; IRASTORZA, Nahikari \& Miri SONG, (2016). "Toward building a conceptual framework on intermarriage," Erişim Tarihi: 22.04.2020, (https://journals.sagepub.com/doi/10.1177/1468796816638402).

ÜNAL, Bayram (2012). "Sürdürülebilir Yasadış1lık, İstanbul'da Gagauz Kadınlar,” Erişim Tarihi:01.09.2017,(https://econpapers.repec.org/article/migjournl/v_3a9_3ay_3a2012_3ai_3a4_3ap _3a387-400.htm).

ÜNLÜTÜRK ULUTAŞ, Çağla ve Alıcan KALFA, (2009). “Göçün Kadınlaşması ve Göçmen Kadınların Örgütlenme Deneyimleri,” Erişim Tarihi: 01.09.2017, (https://cins.ankara.edu.tr/goc.pdf).

YILDIRIM, Ali ve Hasan ŞİMŞEK (2016). Sosyal Bilimlerde Nitel Araştırma Yöntemleri, Ankara: Seçkin Yayıncılık. 
SAĞLAM, Nesibe Ayşe (2021). “Göçmenlikten Yerleşikliliğe: Gagauz Kadınların Evlilik Deneyimleri”, Mavi Atlas, 9(1): 250-274

QİAN, Zhenchao \& Daniel T. LİCHTER, (2011). "Changing Patterns of İnterracial Marriage in a Multiracial Society,” Erişim Tarihi: 28.04.2020, (https://psycnet.apa.org/record/2011-22409012).

QIAN, Zhenchao (1997). "Breaking the Racial Barriers: Varıations In Interracial Marriage Between 1980 and 1990”, Erişim Tarihi: 28.04.2020, (https://pubmed.ncbi.nlm.nih.gov/9169282/).

QİAN, Zhenchao \& Daniel T. LICHTER, (2001). "Measuring Marital Assimilation: Intermarriage among Natives and Immigrants", Erişim Tarihi: 28.04.2020, (https://www.researchgate.net/publication/237259145_Measuring_Marital_Assimilation_Intermarri age_Among_Natives_and_Immigrants). 
SAĞLAM, Nesibe Ayşe (2021). “Göçmenlikten Yerleşikliliğe: Gagauz Kadınların Evlilik Deneyimleri”, Mavi Atlas, 9(1): 250-274

Ek:

Etik Kurul Belgesi

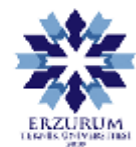

ERZURUM TEKNIK ÜNIVERSITESi

BiLiMSEL ARAŞTIRMA VE YAYıN ETIK KURULU

\section{KARAR}

\begin{tabular}{|c|c|c|}
\hline \multirow{5}{*}{$\begin{array}{l}\text { ETIK } \\
\text { KURULLUN } \\
\text { BILLGİLERI }\end{array}$} & \begin{tabular}{|l} 
ETIK \\
KURULUN ADI
\end{tabular} & Erzurum Teknik Üniversitesi Bilimsel Araştırma ve Yayın Etik Kurulu \\
\hline & ACCIKADRESI & Erzurum Teknik Universitesi Yakutive / ERZURUM \\
\hline & TELEFON & 4445388 \\
\hline & FAX & 04422300046 \\
\hline & E-POSTA & hukuk@erzurum.edu.tr \\
\hline \multirow{2}{*}{\multicolumn{2}{|c|}{$\begin{array}{l}\text { SORUMILU } \\
\text { ARAŞTIRMACILAR } \\
\text { UNVANI/ADI/SOYADI } \\
\text { ARAȘTIRMANINAÇIKADI }\end{array}$}} & Arș. Gör. Nesibe Ayşe SAĞLAM \\
\hline & & "Göçmenlikten Yerleşikliliğe: Gagauz Kadınlarnn Evlilik Deneyimleri" \\
\hline \multirow[b]{2}{*}{$\begin{array}{l}\text { KARAR } \\
\text { BILLGILERİ }\end{array}$} & \multicolumn{2}{|c|}{\begin{tabular}{|llll} 
Toplantı Sayısı : 9 & Karar Sayısı & $: 1$ & Tarih : 27.11.2020 \\
\end{tabular}} \\
\hline & \multicolumn{2}{|c|}{$\begin{array}{l}\text { Yukanda bilgileri verilen başvuru dosyası ile ilgili belgeler araştırmanın gerekçe, amaç, } \\
\text { yaklaşım ve yöntemleri dikkate alınarak incelenmis ve çalş̧manın gerçekleștirilmesinde etik } \\
\text { açıdan sakınca olmadığına toplantrya katılanlann oy birliği ile karar verilmiştir. } \\
\text { Araştırmacılara çalışmalannda başanlar dileriz. }\end{array}$} \\
\hline
\end{tabular}

Prof. Dr. İran KAYMAZ

Üye

Prof. Dr. Songül DUMAN

Üye

Doç. Dr. Nur Hūseyin KAPLAN

Üye
Prof. Dr. Murat KÜC̋̈KUĞURLU Etik Kurul Başkanı

Prof. Dr. Elanur YILMAZ KARABULUTLU

Üye

Prof. Dr. Arzu GÖRMEZ

Üye

Dr. Öğr. Üyesi Emel ZORLUOĞLU

Üye 